\title{
Increasing Hydroperiod in a Karst-depression Wetland Based on 165 Years of Simulated Daily Water Levels
}

\author{
Jennifer M. Cartwright ${ }^{1}$ (D) $\cdot$ William J. Wolfe $^{1}$ (D) \\ Received: 6 April 2021 / Accepted: 9 June 2021 / Published online: 29 June 2021 \\ (C) This is a U.S. government work and not under copyright protection in the U.S.; foreign copyright protection may apply 2021
}

\begin{abstract}
The hydrology of seasonally inundated depression wetlands can be highly sensitive to climatic fluctuations. Hydroperiod — the number of days per year that a wetland is inundated - is often of primary ecological importance in these systems and can vary interannually depending on climate conditions. In this study we re-examined an existing hydrologic model to simulate daily water levels in Sinking Pond, a 35-hectare seasonally inundated karst-depression wetland in Tennessee, USA. We recalibrated the model using 22 years of climate and water-level observations and used the recalibrated model to reconstruct (hindcast) daily water levels over a 165-year period from 1855 to 2019. A trend analysis of the climatic data and reconstructed water levels over the hindcasting period indicated substantial increases in pond hydroperiod over time, apparently related to increasing regional precipitation. Wetland hydroperiod increased on average by 5.9 days per decade between 1920 and 2019, with a breakpoint around the year 1970. Hydroperiod changes of this magnitude may have profound consequences for wetland ecology, such as a transition from a forested wetland to a mostly open-water pond at the Sinking Pond site. More broadly, this study illustrates the needs for robust hydrologic models of depression wetlands and for consideration of model transferability in time (i.e., hindcasting and forecasting) under non-stationary hydroclimatic conditions. As climate change is expected to influence water cycles, hydrologic processes, and wetland ecohydrology in the coming decades, hydrologic model projections may become increasingly important to detect, anticipate, and potentially mitigate ecological impacts in depression wetland ecosystems.
\end{abstract}

Keywords Hydroperiod $\cdot$ Hydrologic model $\cdot$ Karst wetland $\cdot$ Climate change $\cdot$ Non-stationarity $\cdot$ Recalibration

\section{Introduction}

Geographically isolated depression wetlands - such as vernal pools, Carolina bays, playas, and karst sinkhole wetlandsprovide important habitats to plant and animal species and thus support regional biodiversity. However, such depression wetlands may be increasingly vulnerable to anthropogenic climate and landcover change and to human demands on water resources (Tiner 2003; Wolfe et al. 2004; Gómez-Rodríguez et al. 2010; Bird and Day 2014; Bolpagni et al. 2019; Cartwright 2019). Many small depression wetlands are

William J. Wolfe is retired from Lower Mississippi-Gulf Water Science Center, U.S. Geological Survey, Nashville, TN, 37211, USA.

Jennifer M. Cartwright

jmcart@usgs.gov

1 Lower Mississippi-Gulf Water Science Center, U.S. Geological Survey, Nashville, TN 37211, USA seasonally inundated-holding water for only part of each year-with inundation patterns driven by wetland and drainage-basin characteristics (e.g., size, geomorphology, substrate) and climate variability (Brooks 2004; Calhoun et al. 2017; Bertassello et al. 2019; Davis et al. 2019). Primary impacts of climate change and human water use in these depression wetland ecosystems can arise through hydrologic changes such as shifts in seasonal timing of inundation and changes in hydroperiod (i.e., the number of days per year that a wetland is inundated; Brooks 2009; Gómez-Rodríguez et al. 2010; Russell et al. 2020). Because hydroperiod commonly functions as a master control on wetland community composition and ecosystem dynamics (Babbitt 2005; Foti et al. 2012), anticipating wetland ecological trajectories under climate change commonly involves hydrologic modeling to predict and quantify shifts in the hydroperiod regime, i.e. changing patterns of seasonal and interannual variation of inundation over decadal time scales (Greenberg et al. 2015; Lee et al. 2015; Chandler et al. 2016; Qi et al. 2019). The need for such evaluation is heightened by noting that a lag of several decades may separate the 
hydrologically driven crossing of an ecological threshold from the accumulation of effects sufficient to trigger a management response (Wolfe et al. 2004).

Compared to other wetland types, hydrologic modeling of geographically isolated depression wetlands presents a distinct set of challenges. For example, whereas hydroperiod in alluvial wetlands can generally be assessed or at least inferred using streamflow records from streamgage networks (Townsend 2001; Berkowitz et al. 2019), leveraging such networks is more problematic - and in some cases impossiblefor depression wetlands, which tend to be partially or completely disconnected from local surface-drainage systems. Furthermore, hydroperiods of coastal and riverine wetlands are driven by tidal and streamflow regimes that affect large areas, potentially making them more tractable by remotesensing analysis than small depression wetlands where inundation may be partially obscured by canopy cover. Moreover, coastal and alluvial wetlands in many regions have been the subjects of relatively robust research and extensive monitoring networks (e.g., Foti et al. 2012; Crase et al. 2013; Berkowitz et al. 2019), reflecting threats to human infrastructure from floods, storm surges, erosion, etc., inherent in the tidal and streamflow regimes that control hydroperiod in these wetland types. By contrast, availability of hydrologic data and models tends to be more limited for small depression wetlands (Naughton et al. 2012; Cartwright and Wolfe 2016) and commonly focused on their aggregate effects on downstream streamflow rather than their internal hydrodynamics (e.g., Golden et al. 2014; Fossey et al. 2015; Golden et al. 2016; Jones et al. 2019).

Models of depression wetland hydroperiod can vary in a number of important ways, including differences in model architecture (i.e., structure and connectivity of model components such as storage compartments and fluxes between them), differing approaches to model parameterization, and ways to cope with inevitable limitations on availability and spatial resolution of environmental data (Clark et al. 2017). Such differences - especially varying degrees of model complexity - can have major implications for model transferability either in space (i.e., extrapolation to new wetlands in other geographic locations) or in time (i.e., model forecasting to predict future hydrologic conditions or hindcasting to simulate wetland hydrology over the decades prior to the beginning of hydrologic observations; Wenger and Olden 2012; Clark et al. 2017; Lute and Luce 2017). Substantial evidence indicates that model transferability benefits from parsimony, meaning that simpler models (i.e., with fewer parameters and storage compartments) tend to perform as well or better than more complex models when validated using independent data sets (Beven 1989; Jakeman and Hornberger 1993; Leplastrier et al. 2002; Perrin et al. 2003; Chien and Mackay 2014; Lute and Luce 2017; Chien and Mackay 2020). Whereas more complex models may better approximate localized physical processes and generally enable closer fit in calibration, favorable calibration statistics for highly complex models may represent a form of overfitting (i.e., "overparameterization"; Beven 1989; Perrin et al. 2001) causing such models to perform poorly when extrapolated to novel contexts (Wenger and Olden 2012; Lute and Luce 2017; Chien and Mackay 2020). Hydroclimatic non-stationarity (e.g., from climate change) implies that the hydroclimatic conditions of the model calibration and validation time periods (generally the recent past) may be substantially different from those of the more distant past (hindcasting) or future (forecasting), creating potential for transferability problems (Vaze et al. 2010; Coron et al. 2012; Coron et al. 2014; Magand et al. 2015; Duethmann et al. 2020). Thus, when hydroclimatic similarity cannot be assumed between the calibration/validation periods and simulation/prediction periods, model parsimony may be important inasmuch as it increases (or at least does not decrease) model transferability to novel hydroclimatic conditions (Vaze et al. 2010; Coron et al. 2014).

Even for relatively parsimonious hydrologic models, hydroclimatic variability and non-stationarity may necessitate periodic model updates or recalibrations over time (Grigg and Hughes 2018; Duethmann et al. 2020). Because of data limitations, hydrologic models for depression wetlands are commonly calibrated and validated using less than a decade of hydrologic observations (e.g., Sun et al. 2006; Barton et al. 2008; Naughton et al. 2012; Lee et al. 2015; Chandler et al. 2016; Qi et al. 2019). Even in the more data-rich field of streamflow modeling, 25-year datasets are considered "long term" and relatively rare (Chien and Mackay 2014; Chien and Mackay 2020). In this context, calibration and validation datasets typically represent only a subset of the long-term hydroclimatic variability and thus may poorly represent the hydroclimatic extremes of droughts and pluvial periods (Perrin et al. 2001; Kling et al. 2015). Such limitations can constrain methods to assess model transferability to dissimilar hydroclimatic conditions, such as the differential split-sample test (Klemes 1986). These issues make model hindcasting and forecasting especially problematic in regions where hydroclimatic variability is projected to intensify (Karl and Knight 1998; Huntington 2006; Kling et al. 2015), highlighting the importance of periodic model recalibration. While such updates are sometimes performed for widely used streamflow models (e.g., Grigg and Hughes 2018), they are much less common for localized models for depression wetlands.

Here, we revisit a simple two-compartment, four-parameter hydrologic accounting model that simulates daily water levels in Sinking Pond (Wolfe et al. 2004), a 35-ha seasonally ponded karst depression on the Eastern Highland Rim (Fenneman 1938) of Tennessee, USA. Hindcasting from the original model based on about 5 years of continuous waterlevel data showed an abrupt increase in hydroperiod around 1970 , coinciding with reported increases in regional 


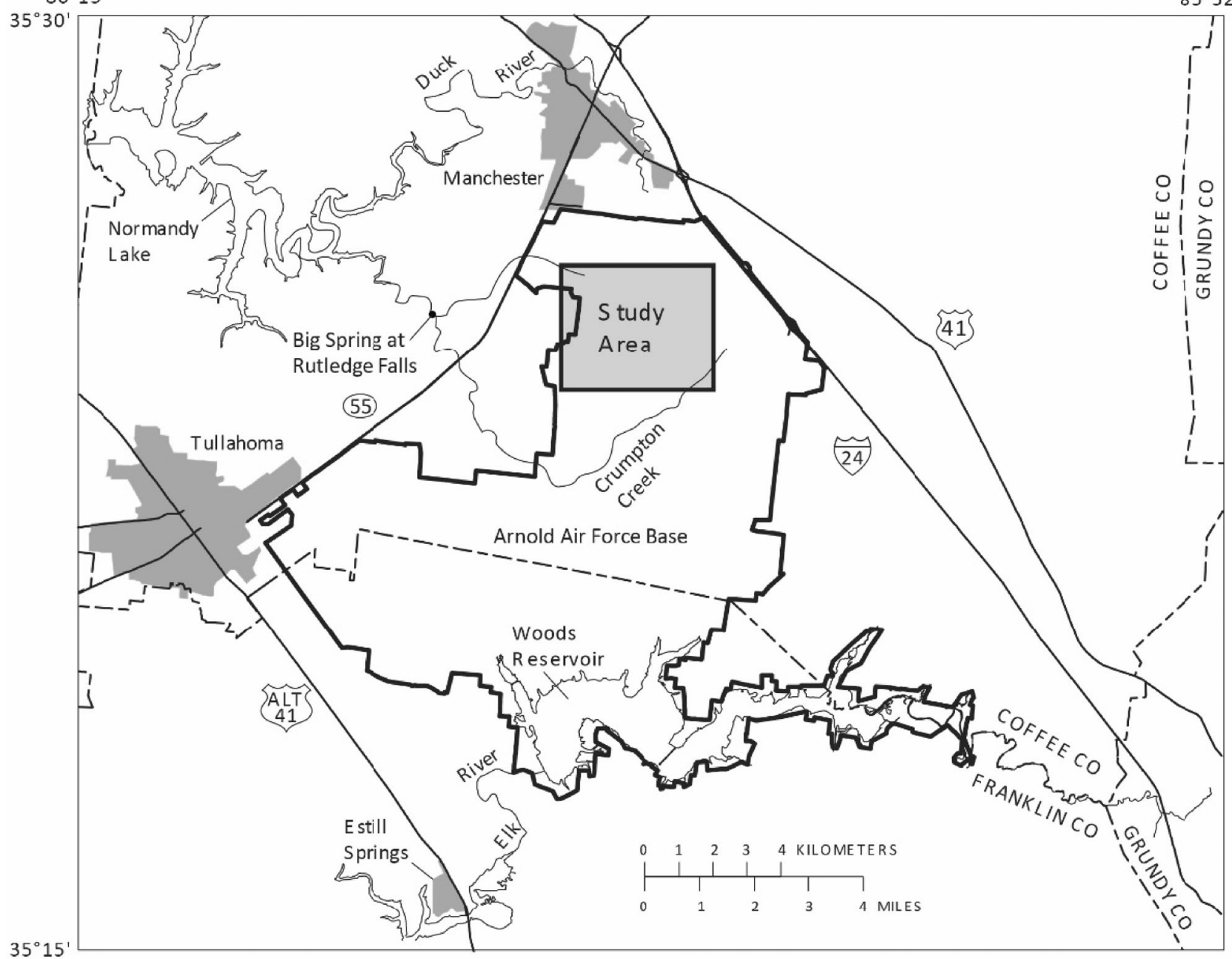

Horizontal coordinate information is referenced to the North American Datum of 1927 (NAD 27).

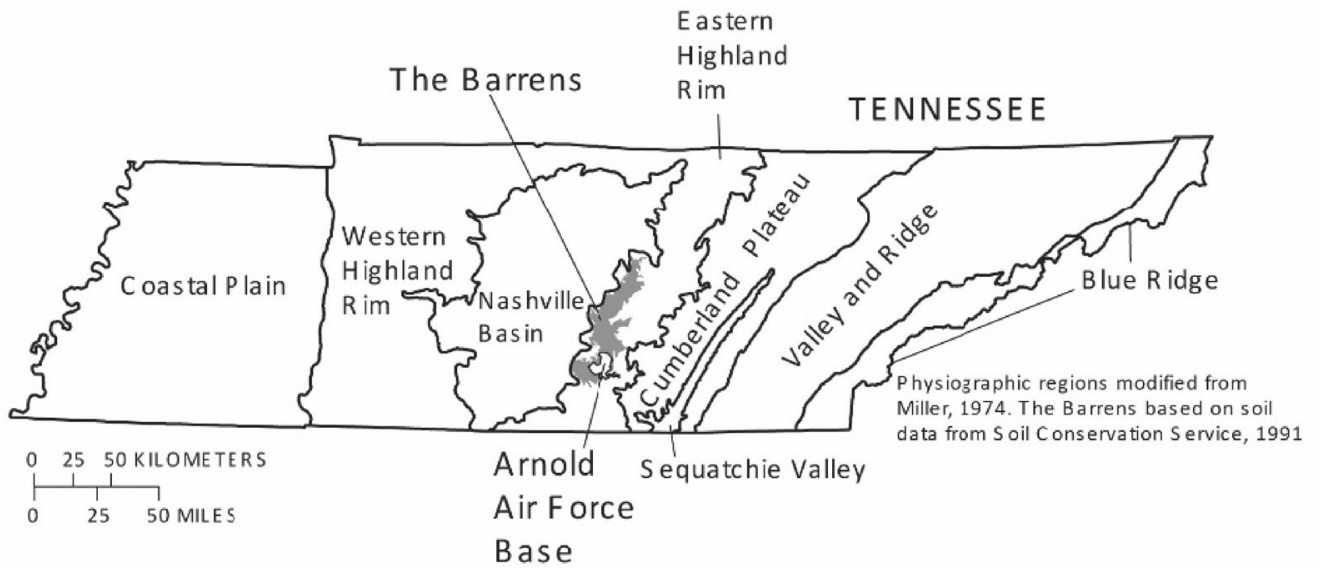

Fig. 1 Location of the Sinking Pond study area within Arnold Air Force Base on the Eastern Highland Rim of Tennessee, USA. Figure modified from Wolfe et al. (2004)

streamflow and precipitation (Karl et al. 1996; McCabe and Wolock 2002) and supported by dendrochronological evidence (Wolfe et al. 2004). This paper presents a revised hydrologic model that preserves the original structure and parameterization (Wolfe et al. 2004) but incorporates an expanded ( 22 versus 5 years) calibration/verification dataset and more robust calibration and verification procedures. Using the recalibrated model, we assessed temporal trends in 
precipitation and temperature across a 165 -year simulation period (1855-2019) and compared seasonal and interannual variability of precipitation and temperature among the input dataset and two calibration/verification datasets. We show that the model revision reduced bias and improved performance and that the revised simulated time series of pond stage supports the previous conclusion that increased precipitation since around 1970 has driven a discernible increase in Sinking Pond's hydroperiod.

\section{Data and Methods}

\section{Site Description}

Sinking Pond is a 35-ha seasonally inundated karst-depression wetland located on Arnold Air Force Base, Tennessee, USA, within the Eastern Highland Rim subsection of the Interior Low Plateaus physiographic province (Fig. 1; Fenneman and Johnson 1946). The name "Sinking Pond" refers to the abrupt seasonal rises and falls of pond water levels. For example, the pond can transform from a fully drained condition to $2 \mathrm{~m}$ or more of inundation within one or two days (Wolfe et al. 2004). In most years, Sinking Pond becomes inundated in autumn or winter, remains inundated through spring, and drains by mid to late summer. The deepest parts of Sinking Pond are narrow, steep-sided swallets and their interconnecting channels that constitute a relatively small percent of pond area and are topographically distinct from the broad expanse of shallower and flatter areas at higher elevations within the pond. Sinking Pond's internal drainage system - a network of coalesced sinkholes and connected karst conduits - receives concentrated recharge from the Sinking Pond basin (Wolfe 1996a; Wolfe et al. 2004; Haugh 2006). Surface water flows

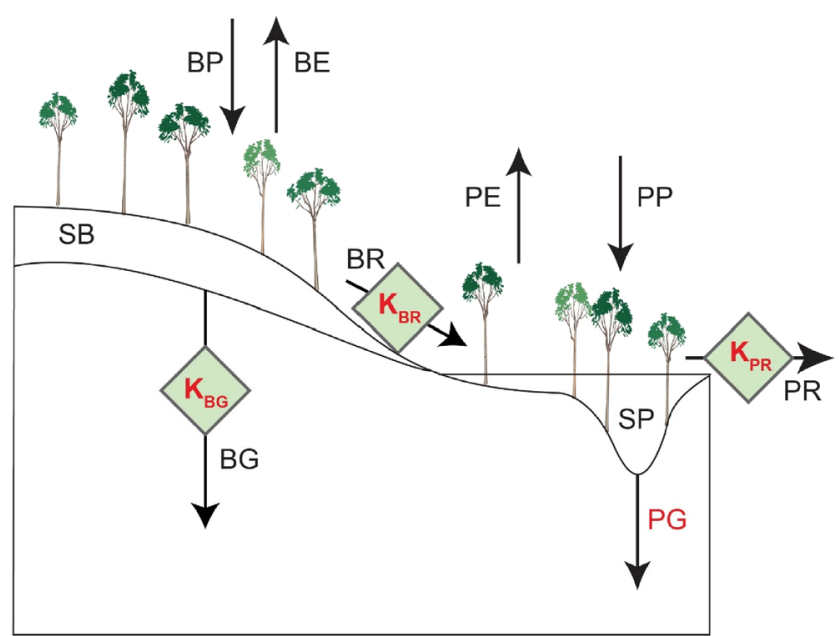

Fig. 2 Conceptual diagram of the Sinking Pond hydrologic model showing daily flux variables (arrows), daily state variables (SB and SP), and rate coefficients (green diamonds). Model terms subject to calibration are in red. All abbreviations are defined in Table 1 seasonally to Crumpton Creek, a tributary of the Duck River (Fig. 1). Groundwater in the Sinking Pond area follows a flow path roughly parallel to Crumpton Creek and discharges through several springs, of which the most prominent is Big Spring at Rutledge Falls (Fig. 1; Haugh 2006).

Sinking Pond is located within The Barrens: a region characterized by open-canopy ecosystems including prairie-like "barrens", oak savannas, and woodlands, with ponds and other wetlands embedded throughout a landscape of low $(<20 \mathrm{~m})$ relief and thick, infertile soils atop karstic Mississippian limestone (Wolfe 1996a; Pyne 2000). The study site has mean annual precipitation of roughly $150 \mathrm{~cm}$ and monthly mean temperatures ranging from $2.7^{\circ} \mathrm{C}$ in January to $25^{\circ} \mathrm{C}$ in July (Wolfe et al. 2004). Landcover is primarily temperate broadleaf forest (Wolfe et al. 2004). Vegetation within the 335-ha Sinking Pond basin ranges from oak-hickory (Quercus-Carya) forest along well-drained slopes and ridges to stands of sweetgum (Liquidambar styriciflua), blackgum (Nyssa sylvatica), red maple (Acer rubrum), and willow oak (Quercus phellos) in poorly drained areas; water tupleo (Nyssa aquatica), overcup oak (Quercus lyrata), and river birch (Betula nigra) dominate the deepest or most frequently inundated zones (Patterson 1989; Wolfe 1996a; Wolfe et al. 2004).

\section{Climate Data}

Daily precipitation and temperature values from January 1, 1854 through September 30, 2019 served as inputs to the Sinking Pond hydrologic model. Precipitation and temperature observations were compiled from National Centers for Environmental Information (NCEI) weather stations in the vicinity of the study site (National Centers for Environmental Information 2020), as described by Wolfe et al. (2004). Daily precipitation and temperature records beginning March 1, 1893 and February 1, 1895, respectively, were primarily from the station in Tullahoma, Tennessee (NCEI station 409,155). Gaps in the Tullahoma record (approximately $0.1 \%$ of daily records) were filled using records from the station in McMinnville, Tennessee (NCEI station 405,882 ), according to Wolfe et al. (2004). Daily precipitation and temperature records prior to March 1, 1893 and February 1, 1895, respectively, were produced by disaggregating monthly temperature records. Disaggregation was performed by scaling reference daily values using ratios of the monthly values being disaggregated divided by the corresponding reference monthly values. Wolfe et al. (2004) describe selection of reference values and the disaggregation procedure in detail.

\section{Stage Data}

Daily measurements of pond stage (i.e., gage height) at the Sinking Pond study site were obtained from U.S. Geological 
Table 1 Key components of the Sinking Pond hydrologic model

\begin{tabular}{llll}
\hline Model term & Explanation & Units & Type \\
\hline $\mathrm{BP}$ & Precipitation into basin outside pond & $\mathrm{Bcm}$ & Daily flux variable \\
$\mathrm{PP}$ & Precipitation into pond & $\mathrm{Bcm}$ & Daily flux variable \\
$\mathrm{SB}$ & Basin storage & $\mathrm{Bcm}$ & Daily state variable \\
$\mathrm{SP}$ & Pond storage & $\mathrm{Bcm}$ & Daily state variable \\
$\mathrm{BG}$ & Basin groundwater recharge & $\mathrm{Bcm}$ & Daily flux variable \\
$\mathrm{BR}$ & Basin runoff into pond & $\mathrm{Bcm}$ & Daily flux variable \\
$\mathrm{BE}$ & Basin evapotranspiration & $\mathrm{Bcm}$ & Daily flux variable \\
$\mathrm{PG} *$ & Pond groundwater recharge & $\mathrm{Bcm}$ & Daily flux constant \\
$\mathrm{PR}$ & Pond runoff & $\mathrm{Bcm}$ & Daily flux variable \\
$\mathrm{PE}$ & Pond evapotranspiration & $\mathrm{Bcm}$ & Daily flux variable \\
$\mathrm{K}_{\mathrm{BR}}{ }^{*}$ & Basin runoff rate coefficient & $\mathrm{NA}$ & Rate coefficient \\
$\mathrm{K}_{\mathrm{PR}}{ }^{*}$ & Pond runoff rate coefficient & $\mathrm{NA}$ & Rate coefficient \\
$\mathrm{K}_{\mathrm{BG}}{ }^{*}$ & Basin groundwater-recharge rate coefficient & $\mathrm{NA}$ & Rate coefficient \\
\hline
\end{tabular}

Notes: *denotes model parameters subject to calibration; bcm = basin centimeters (the Sinking Pond basin has an area of 335 hectares, such that $1 \mathrm{bcm}=33,500 \mathrm{~m}^{3}$ ); relationships between model terms are shown in Fig. 2 and Eqs. 2 and 3.
Survey site number 03596075 ("Sinking Pond at AEDC, TN"; U.S. Geological Survey 2020). Records from this gage began in September 1992 and continued, with some interruptions, through and beyond the end of this study in September 2019. Water years (annual periods beginning October 1 of the previous calendar year and ending September 30 of the calendar year) from 1993 to 2019 with no more than $10 \%$ missing daily records were used for model recalibration (Online Resource 1).

\section{Model Formulation}

Using a classical water-budget approach, a hydrologic model was developed to evaluate climate-driven hydrologic changes at the Sinking Pond study site. This model is described in detail by Wolfe et al. (2004) and summarized briefly here. On a daily time-step, the model accounts for precipitation and runoff inputs to the pond and outflows to the atmosphere, surface water, and the local groundwater system (Fig. 2). The model begins with a basic water budget (Eq. 1):

$\mathrm{P}+\mathrm{GI}+\mathrm{RI}=\Delta \mathrm{S}+\mathrm{GO}+\mathrm{RO}+\mathrm{ET}$

where $\mathrm{P}$ is precipitation, GI is groundwater inflow, RI is surface-runoff inflow, $\Delta \mathrm{S}$ is change in volume of stored water (i.e., storage), GO is groundwater outflow, RO is surfacerunoff outflow, and ET is evapotranspiration. Equation 1 is then decomposed into two linked functions (Eqs. 2 and 3) representing the contributing basin and Sinking Pond, respectively:

$\mathrm{BP}=\Delta \mathrm{SB}+\mathrm{BG}+\mathrm{BR}+\mathrm{BE}$

and
$\mathrm{PP}+\mathrm{BR}=\Delta \mathrm{SP}+\mathrm{PG}+\mathrm{PR}+\mathrm{PE}$

where BP is precipitation falling on the contributing basin outside the pond, $\mathrm{SB}$ is water storage in the basin vadose zone outside the pond, BG is groundwater recharge from the basin vadose zone, BR is surface runoff from the basin into the pond, $\mathrm{BE}$ is ET from the basin outside the pond, $\mathrm{PP}$ is precipitation falling on the pond, SP is water storage in the pond, $\mathrm{PG}$ is groundwater recharge from the pond, PR is surface runoff from the pond, and PE is ET from the pond (Fig. 2; Table 1). Daily flux and storage terms were expressed in basin centimeters (bcm; Table 1). Pond volume was calculated from daily SP values and then transformed into daily modeled stage values using a stage-volume rating curve from Wolfe et al. (2004).

Four model terms were subject to calibration (Fig. 2; Table 1). Three of these terms $\left(\mathrm{K}_{\mathrm{BG}}, \mathrm{K}_{\mathrm{BR}}\right.$, and $\left.\mathrm{K}_{\mathrm{PR}}\right)$ are rate coefficients that scale water transfers from a given compartment of the model (i.e., the basin or pond) to storage in that compartment (i.e., SB or SP) at each time step. The $\mathrm{K}_{\mathrm{BR}}$ and $K_{P R}$ runoff coefficients determine daily runoff from the basin and pond, respectively, as functions of storage (i.e., SB and $\mathrm{SP})$. The $\mathrm{K}_{\mathrm{BG}}$ coefficient determines the daily groundwater recharge flux from the basin vadose zone as a function of SB. The fourth calibrated model term, $\mathrm{PG}$, represents recharge from the pond when it contains water and accumulation of groundwater-storage deficit when the pond is drained. PG is conceptualized as a constant daily flux value, in part because characterizing hydraulic gradients is problematic when the pond is drained but also because the notable absence of seasonal and diurnal variability in discharge at Big Spring (Williams and Farmer 2003; Haugh 2006; see site 
description) suggests that a relatively steady accumulation of groundwater deficit is physically plausible.

Daily potential evapotranspiration (PET) was calculated using daily temperature and an empirically determined PET scaling factor, based on published annual pan evaporation rates (Wolfe et al. 2004). BE and PE were calculated using PET and storage (i.e., SB and SP, respectively), as well as basin and pond water-availability thresholds as described in Wolfe et al. (2004). The upper boundary conditions for storage in the basin and pond are constrained by runoff generation once basin-soil saturation or pond filling is exceeded (SB or $\mathrm{SP}>0$ ). The lower bound of basin storage is set by a spatially weighted average available moisture capacity of $-23.4 \mathrm{bcm}$ (Wolfe et al. 2004). We opted not to impose an explicit lower limit on pond storage because that would have required a fifth model calibration term, increasing model complexity and the risk of overfitting (i.e., improved calibration fit without necessarily improving model simulation). Thus, the model allows pond storage deficits to accumulate until reversed through recharge driven by precipitation and basin-runoff inputs. This storage conceptualization was reasonable given the thickness of the limestone substrate in which Sinking Pond is embedded, however, we note that this conceptualization may not be transferable to other wetlands with different hydrogeologic characteristics.

\section{Original Model Calibration}

Original calibration of the Sinking Pond hydrologic model, as presented in Wolfe et al. (2004), used a 2-year calibration period (i.e., observed stage records) from February 1993 through February 1995 and a 3-year validation period (water years 2000 through 2002). Model calibration and validation were performed using graphical comparison of observed and modeled values for pond volume, pond stage, and pond runoff (Wolfe et al. 2004). Notably, this original calibration process did not include an assessment of how the calibration and validation water years compared to the simulation period of record (water years 1855 through 2002) in terms of the distributions and variability of temperature and precipitation, nor any explicit evaluation of water years with anomalous climate conditions (e.g., very wet or very dry years).

We assessed the performance of the original model calibration from Wolfe et al. (2004) using an updated dataset containing an additional 17 years (22 years total) of climate and stage observations (Online Resource 1). We assessed calibration performance using three quantitative metrics, along with graphical comparisons of modeled versus observed stage hydrographs for each water year. The first two quantitative metrics, root mean-squared error (RMSE) and Nash-Sutcliffe Efficiency (NSE), are commonly used in hydrologic model calibration (Ritter and Muñoz-Carpena 2013; Moriasi et al. 2015). In addition to calculating NSE using daily values across all water years, we also calculated NSE for each water year independently and then recorded the 25 th percentile of these annual NSE values $\left(\mathrm{NSE}_{\mathrm{p} 25}\right)$. The $\mathrm{NSE}_{\mathrm{p} 25}$ metric provides a means of assessing model performance for the 5 water years (out of 22) that were the least well-predicted by the model. To complement RMSE and NSE, we developed a third metric, which we refer to as hydroperiod discrepancy (HPD), to represent the degree to which the calibrated model overpredicted $(\mathrm{HPD}>0)$ or underpredicted $(\mathrm{HPD}<0)$ pond hydroperiod. Hydroperiod is defined here as the number of days in each water year with pond stage $\geq 323 \mathrm{~m}$. We selected this stage value for the hydroperiod definition because it is approximately mid-way between the stage at which the pond is dry (approximately $321.5 \mathrm{~m}$ ) and the spillway elevation (approximately $324.5 \mathrm{~m}$ ). Because of the pond-basin topography, the pond contains very little water at a pond stage of $323 \mathrm{~m}$, with pond volume of roughly $2.5 \%$ of the spillwaystage pond volume. Because Sinking Pond typically fills and drains rapidly each year (Wolfe et al. 2004), selection of a slightly different stage value to define hydroperiod would have had minimal effect on the calculated hydroperiods. HPD was calculated as percent overprediction of the observed pond hydroperiod following Eq. (4):

$\mathrm{HPD}=\frac{\mathrm{HP}_{M} \mathrm{HP}_{O}}{\mathrm{HP}_{O}} \times 100$

where $\mathrm{HP}_{\mathrm{M}}$ and $\mathrm{HP}_{\mathrm{O}}$ are modeled and observed pond hydroperiod, respectively.

\section{Model Recalibration}

Recalibration of the Sinking Pond hydrologic model relied on the full 22 water years of daily observed pond stage (Online Resource 1), because this approach has been demonstrated to produce the most robust parameter sets (Arsenault et al. 2018). Recalibration involved evaluating all possible combinations of the model parameters subject to calibration $\left(\mathrm{K}_{\mathrm{BG}}, \mathrm{K}_{\mathrm{BR}}\right.$, $\mathrm{K}_{\mathrm{PR}}$, and $\mathrm{PG}$ ) using the ranges and intervals in Online Resource 2, which produced 81,900 potential calibrations (i.e., unique combinations of model parameters) to be evaluated. For each potential calibration, the model was run on a daily time step from January 1, 1854 through September 30, 2019 , to produce daily values of modeled pond stage over this time period. Modeled pond stage was then compared to the daily values of observed pond stage over 22 water years (Online Resource 1) to calculate model performance metrics (RMSE, NSE, $\mathrm{NSE}_{\mathrm{p} 25}$, and HPD). In this way, model performance metrics were generated for each of the 81,900 potential calibrations considered (Cartwright 2021).

Recalibration of the Sinking Pond hydrologic model was then conducted using a hierarchical multi-objective calibration procedure. First, a subset of potential 
calibrations was identified having NSE $\geq 98 \%$ of the maximum NSE value across all potential calibrations, with NSE having been calculated across all water years in the recalibration dataset. This first criterion ensured that the final calibration had near-optimal NSE. Second, a reduced subset of potential calibrations was identified having $\mathrm{HPD} \leq \pm 2 \%$. This second criterion ensured that the final calibration was not biased in approximating pond hydroperiod. Lastly, from the subset of potential calibrations meeting the first two criteria, the final calibration was selected which had the highest value of $\mathrm{NSE}_{\mathrm{p} 25}$, which optimized model representation of the five worstperforming water years. We did not use RMSE as a recalibration criterion because it was largely redundant to NSE (correlation $=-0.98, \mathrm{p}<0.001$ ).

We validated the recalibration approach using leaveone-out cross-validation (LOOCV). Iteratively for each water year in the recalibration dataset, we (1) withheld the water year in question and performed model calibration using data from all other water years, (2) used the resulting calibration to generate modeled daily stage values for the withheld water year, and (3) compiled modeled daily stage values for all water years in this manner, one year at a time. We then calculated model performance metrics (RMSE, NSE, and HPD) using the modeled daily stage values for the entire recalibration period of record that were generated by the LOOCV process.
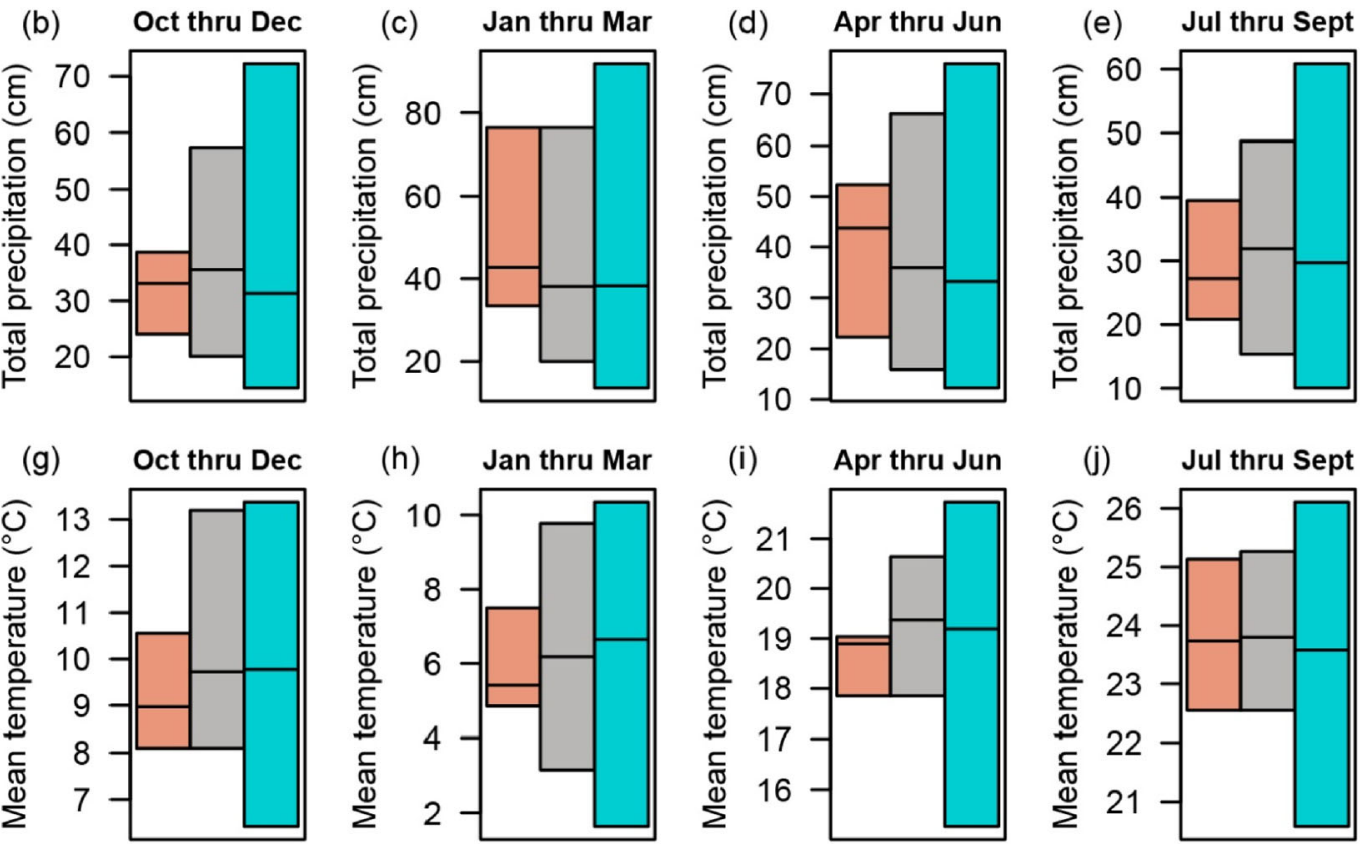

Fig. 3 Variability in (a-e) total precipitation and $(\mathbf{f}-\mathbf{j})$ mean temperature for water years used in the Sinking Pond hydrologic model. Orange: 5 water years used in the original model calibration and validation; gray: 22 water years used in model recalibration; blue: 165 water years used in model simulation (i.e., hindcasting) from 1855 through 2019. All boxes

\section{Hydrologic Simulation (hindcasting)}

Because the model ran on a daily time step using climate inputs from January 1, 1854 through September 30, 2019, modeled daily stage values over a 165-year period (water years 1855 through 2019) could then be used to simulate (i.e., hindcast) historical patterns of pond hydroperiod and hydrologic responses to climatic variability. The start date for hydrologic simulation was set to January 1, 1854 to give the model time to stabilize before the period of analysis beginning October 1, 1854 (i.e., the start of the 1855 water year) and because a January start date makes plausible an initial condition where both the basin and the pond compartments were at full saturation (i.e., not producing runoff but ready to do so with an incremental input of water to either compartment).

\section{Analysis of Climate Variability}

We assessed climate variability by examining ranges and median values of temperature and precipitation across water years and by season (October through December, etc.). We compared climate variability across three time periods: (1) the period of record (POR) used in the original model calibration and validation (5 water years; Online Resource 1), (2) the recalibration POR (22 water years; Online Resource 1), and (3) the hindcasting POR (165 water years from 1855 to 2019). This analysis allowed an appraisal of how well the model
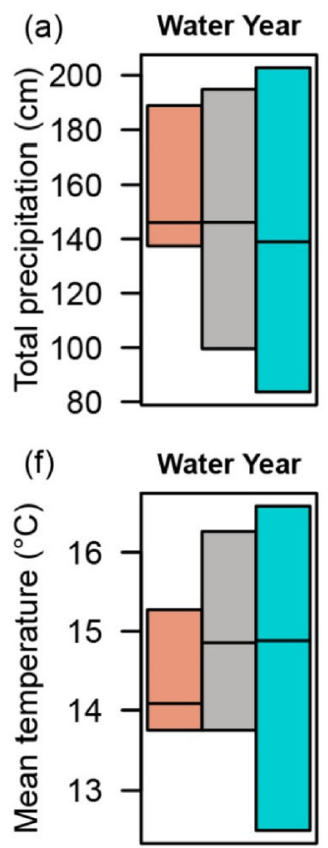

(f) show minimum, maximum, and median values. Boxes in (a) and (f) show variability across entire water years (October 1 through September 30 ). Boxes in (b) through (e) and (g) through (j) show variability within quarters of water years 
calibration and recalibration represented the climatic variability of the simulation period.

\section{Trend Analysis}

Using the 165-year daily time series of simulated pond-stage values from the recalibrated model over the hindcasting period (1855-2019), we checked for possible hydroperiod trends using three common test statistics: Mann-Kendall (Mann 1945; Kendall 1975; Yue et al. 2002a), Pettitt (1979), and Sen's slope (1968). We also checked for trends in climate variables driving the model, including precipitation, temperature, and water balance (precipitation minus potential evapotranspiration, PET). We checked for serial autocorrelation in annual climate variables and hydroperiod by computing the sample autocorrelation function using time lags from one to 20 years (Yue et al. 2002b). We visualized trends in climate variables and hydroperiod using boxplots to depict variability within three 50-year periods: 1870-1919, 1920-1969, and 1970-2019. Splitting the time series in this way allowed us to compare climate variables and hydroperiod pre- and post1970 , based on previously identified hydrologic changes circa 1970 at this site (Wolfe et al. 2004) and the broader region (Karl et al. 1996; McCabe and Wolock 2002). We quantified differences among these 50-year periods using analysis of variance (ANOVA) and Tukey's post-hoc tests.

To check whether trends in the precipitation records used in the Sinking Pond hydrologic model were consistent or discrepant with larger regional patterns of precipitation trends (or lack thereof), we obtained precipitation records from National Centers for Environmental Information (2020) for all NCEI weather stations located within $100 \mathrm{~km}$ of the Sinking Pond study site having at least 70 years of annual precipitation data between 1920 and 2019, which yielded 8 weather stations (Online Resource 3). For each station, we performed a Mann-Kendall test on total annual precipitation and on the number of precipitation days, defined by NCEI as the number of days per year with at least $0.254 \mathrm{~mm}$ of precipitation. All modeling and analyses were performed in the $\mathrm{R}$ statistical language (R Core Team 2017) using the $\mathrm{R}$ packages Kendall (McLeod 2011), trend (Pohlert 2020), and forecast (Hyndman et al. 2020). Data and R processing scripts used in this study are available from Cartwright (2021).

\section{Results}

\section{Climate Variability Represented by the Sinking Pond Hydrologic Model}

As expected, interannual variability in precipitation and temperature was greater across the 22 water years used in model recalibration than across the 5 years used in the original calibration/validation (Fig. 3). Compared to the original calibration dataset, climatic variability across the recalibration water years more closely approximated the range of climatic conditions in the model simulation (hindcasting) period from 1855 to 2019; however, precipitation and temperature extremes across the simulation period were still not fully captured by the 22 water years used in model recalibration. Relatively dry water years (total precipitation $<130 \mathrm{~cm}$ ) accounted for roughly a third of water years in the simulation period ( 57 years) but were completely absent from the dataset used in the original calibration. The updated dataset used in recalibration contained four such dry years (18\% of recalibration years), including two extremely dry years (2007 and 2008) with slightly less than $100 \mathrm{~cm}$ total precipitation. Similarly, warm years in the simulation period (mean annual
Table 2 Model parameters and performance metrics for the original calibration and recalibration of the Sinking Pond hydrologic model

\begin{tabular}{lll}
\hline & Original calibration & Recalibration \\
\hline Number of water years used for calibration & 5 & 22 \\
Calibrated model parameters & & \\
$\mathrm{K}_{\mathrm{BR}}$ & 0.20 & 0.35 \\
$\mathrm{~K}_{\mathrm{PR}}$ & 0.50 & 0.45 \\
$\mathrm{~K}_{\mathrm{BG}}$ & 0.12 & 0.12 \\
$\mathrm{PG}$ & 0.0762 & 0.07 \\
Model performance metrics & & \\
RMSE (m) & 0.86 & 0.73 \\
Nash-Sutcliffe Efficiency (NSE) & 0.63 & 0.74 \\
Hydroperiod discrepancy (\%) & -19.57 & -1.74 \\
NSE & 0.54 & 0.72 \\
\hline
\end{tabular}

Notes: Model parameters are defined in Table $1 . \mathrm{NSE}_{\mathrm{p} 25}$ is the 25th percentile of NSE values across water years. Model performance metrics for both the original calibration and recalibration were calculated using the 22 water years in the recalibration period of record (Online Resource 1). 

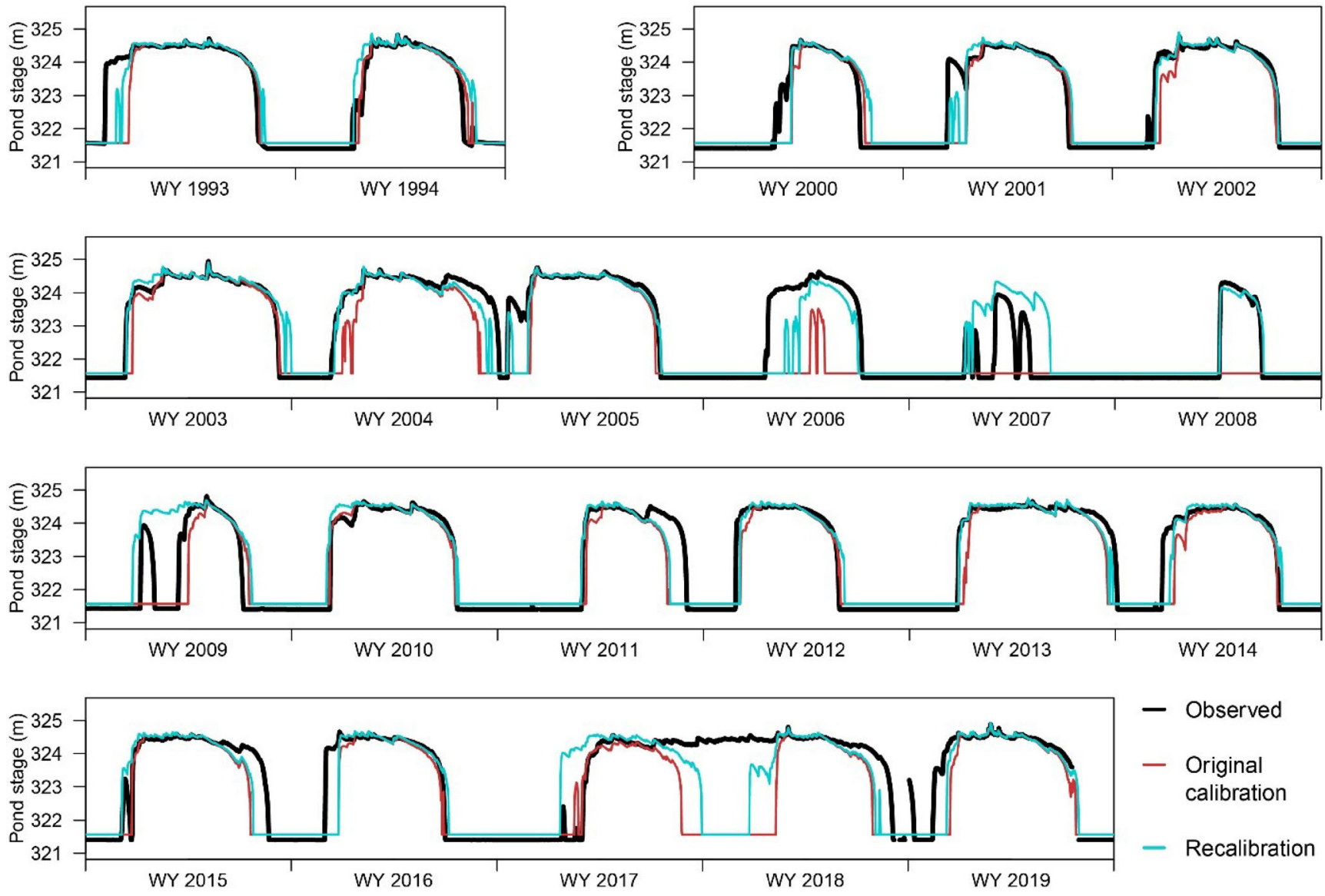

- Observed

- Original calibration

- Recalibration

Fig. 4 Hydrographs showing pond stage for the 22 water years in the period of record used for recalibration of the Sinking Pond hydrologic model. Tick marks on the horizontal axis show starts of each water year (WY) on October 1

temperature $>15.5^{\circ} \mathrm{C}$ ) were unrepresented by the original calibration but were represented by four years $(18 \%)$ in the recalibration. Improvements in representation of interannual climatic variability for the recalibration over the original calibration were especially pronounced for years with high October through December precipitation (Fig. 3b), high October through December temperatures (Fig. 3g), and low January through March temperatures (Fig. 3h). Notably, very cold water years in the simulation period were not well represented by either the original calibration or the recalibration, when examining entire water years (Fig. 3f) or three of the four quarters (Fig. 3g, i and j).

\section{Performance of the Original Model Calibration and Recalibration}

Model performance was improved by the recalibration compared to the original model calibration according to all performance metrics calculated using the 22 water years in the recalibration period of record (Table 2, Online Resource 4). Model recalibration reduced RMSE by approximately $0.13 \mathrm{~m}(13 \mathrm{~cm})$ and increased NSE by approximately 0.1 . For 14 out of 22 water years (64\%), NSE was increased by the recalibration relative to the original calibration (Online Resource 5). Model bias in approximating pond hydroperiod was dramatically reduced by recalibration: whereas hydroperiod was underestimated by almost $20 \%$ using the original calibration, the recalibration procedure reduced hydroperiod bias to within $2 \%$ (Online Resource 4). For 16 water years (73\%), hydroperiod discrepancy was improved (i.e., became closer to zero) by the recalibration (Online Resource 5). Moreover, model performance in unusual or difficult-topredict water years was improved by the recalibration, as indicated by an increase in $\mathrm{NSE}_{\mathrm{p} 25}$ of almost 0.2 (Table 2, Online Resource 4).

Two model parameters $-\mathrm{K}_{\mathrm{BG}}$ and $\mathrm{PG}$, representing groundwater recharge from the basin and pond, respectively - were largely unchanged by model recalibration (Table 2). Of the remaining two parameters, $\mathrm{K}_{\mathrm{BR}}$ was increased and $\mathrm{K}_{\mathrm{PR}}$ was decreased by the recalibration, reflecting increased basin runoff into the pond and decreased surface runoff from the pond, respectively. Changes in these two model parameters both served to increase pond storage and corresponding hydroperiod and thus were largely effective in removing hydroperiod bias from the model (i.e., reducing overall underestimation of pond hydroperiod close to zero). 
Table 3 Means and standard deviations of model terms from the recalibrated Sinking Pond hydrologic model

\begin{tabular}{lllll}
\hline Model term & $\begin{array}{l}\text { Calibration period } \\
\text { (22 years) }\end{array}$ & $\begin{array}{l}\text { Entire period of record: } \\
1855 \text { through } 2019 \\
(165 \text { years })\end{array}$ & $\begin{array}{l}1855 \text { to } 1969 \\
\text { (115 years) }\end{array}$ & $\begin{array}{l}1970 \text { to } 2019 \\
\text { (50 years) }\end{array}$ \\
\hline BP & $0.364(0.944)$ & $0.342(0.9)$ & $0.33(0.866)$ & $0.372(0.973)$ \\
PP & $0.04(0.105)$ & $0.038(0.1)$ & $0.037(0.096)$ & $0.041(0.108)$ \\
SB & $-6.305(7.181)$ & $-6.734(7.13)$ & $-6.964(7.144)$ & $-6.199(7.068)$ \\
SP & $-5.915(4.825)$ & $-6.993(5.309)$ & $-7.481(5.312)$ & $-5.863(5.129)$ \\
BG & $0.034(0.102)$ & $0.031(0.097)$ & $0.029(0.091)$ & $0.036(0.108)$ \\
BR & $0.101(0.299)$ & $0.09(0.282)$ & $0.083(0.266)$ & $0.105(0.316)$ \\
BE & $0.23(0.187)$ & $0.222(0.18)$ & $0.218(0.178)$ & $0.231(0.185)$ \\
PG & $0.07(0)$ & $0.07(0)$ & $0.07(0)$ & $0.07(0)$ \\
PR & $0.054(0.215)$ & $0.042(0.187)$ & $0.035(0.164)$ & $0.059(0.23)$ \\
PE & $0.018(0.02)$ & $0.016(0.019)$ & $0.015(0.019)$ & $0.018(0.02)$ \\
\hline
\end{tabular}

Notes: Model terms are defined in Table 1. All units are in basin centimeters; $1 \mathrm{bcm}=33,500 \mathrm{~m}^{3}$. Values represent means (with standard deviations in parentheses) across the time periods noted; PG was defined as a constant flux with its value determined through calibration
Changes in the hydrologic simulation produced by the recalibration were especially apparent for the 2006, 2007, and 2008 water years (Fig. 4, Online Resource 5), the three water years in the recalibration period of record with lowest annual precipitation. Although pond inundation did occur in these drought years, the model under the original calibration either failed to fill at all (2007 and 2008) or was inundated only briefly (2006), producing large underestimates of pond hydroperiod (Online Resource 5). Model recalibration substantially improved performance in two of these drought years, lessening the underprediction of hydroperiod in 2006 and representing hydroperiod almost perfectly in 2008. In 2007, recalibration shifted the model from complete underprediction of hydroperiod (no simulated pond filling), to a roughly $200 \%$ hydroperiod overprediction.

Recalibration also produced moderate improvements under unusually wet conditions in 2017 and 2018 (Fig. 4). Both water years had above average annual precipitation (by approximately 16 and $22 \mathrm{~cm}$, respectively) and the 2017 growing season was especially wet, with April through June and July through September precipitation roughly 8 and $14 \mathrm{~cm}$ above average, respectively. July through September conditions in 2017 were also abnormally cool $\left(0.7^{\circ} \mathrm{C}\right.$ below average). As a result, Sinking Pond never drained at the end of the 2017 water year, instead remaining inundated from late winter of 2017 until early autumn of 2018 (Fig. 4). Although neither the original calibration nor the recalibration successfully replicated this unusual event, the recalibrated model drained later and filled earlier than the original calibration, thus performing slightly better during these unusually cool and wet conditions. We also note that although the recalibrated model was largely successful in simulating pond stage and hydroperiod in most water years, it was considerably less successful in years with unusually complex hydrographs such as years with multiple filling and draining events (e.g., 2007 and 2009; Fig. 4, Online Resource 5).
For many water years in the hindcasting period (1855 through 2019), simulated pond stage and hydroperiod were largely unchanged by the recalibration relative to the original calibration (Online Resource 6). However, overall increases in simulated hydroperiod produced by the recalibrationpresumably resulting from the substantial correction of hydroperiod bias-were apparent for several water years in the hindcasting period, particularly for water years for which simulated hydroperiod had been particularly low under the original calibration.

The LOOCV process produced a distribution of model parameters (i.e., calibrated parameters that differed across the water years as each was withheld for validation; Online Resources 7 and 8) that was generally similar to the parameter values from the recalibrated hydrologic model (Table 2). Model performance metrics from the LOOCV process varied across water years withheld for validation (Online Resources 7 and 8). Performance metrics from LOOCV were poor for a few atypical water years, including 2007, 2009, and 2017-18 which contained more than one distinct period of pond inundation or in which pond drainage did not occur (Fig. 4) but were generally acceptable in most water years (Online Resource 8).

Based on the recalibrated model, inputs to the pond were dominated by BR, which averaged roughly 2.5 times the magnitude of PP; pond outflows were dominated by PG and PR, with PE accounting for roughly one-eighth of pond outflows (Table 3).

\section{Trends in Pond Hydroperiod and Climate Variables}

Simulated hydroperiod from the recalibrated model showed clear positive trends over time (Fig. 5), related to increases in total annual precipitation and water balance (precipitation minus PET; Figs. 5 and 6; Table 4). Based on Sen's slope 
Table 4 Analysis of trends in climate and hydroperiod from the Sinking Pond hydrologic model

\begin{tabular}{|c|c|c|c|c|c|c|c|c|}
\hline \multirow[b]{2}{*}{ Entire period of record: 1855 through 2019} & \multicolumn{2}{|c|}{ Mann-Kendall test } & \multicolumn{2}{|c|}{$\begin{array}{l}\text { Sen's slope } \\
\text { (change per decade) }\end{array}$} & \multicolumn{2}{|l|}{ Pettitt's test } & \multicolumn{2}{|c|}{$\begin{array}{l}\text { Autocorrelation } \\
\text { (correlation coefficient) }\end{array}$} \\
\hline & Tau & P-value & Estimate & $95 \% \mathrm{CI}$ & Break-point year & P-value & Maximum & 1-year lag \\
\hline Total annual precipitation $(\mathrm{cm})$ & 0.247 & $<0.001$ & 1.865 & {$[1.150,2.634]$} & 1942 & $<0.001$ & 0.19 & 0.19 \\
\hline Mean annual temperature $\left({ }^{\circ} \mathrm{C}\right)$ & 0.191 & $<0.001$ & 0.047 & {$[0.021,0.074]$} & 1905 & $<0.001$ & 0.31 & 0.25 \\
\hline Annual precipitation minus PET (cm) & 0.067 & 0.20 & 0.547 & {$[-0.305,1.408]$} & 1970 & 0.14 & 0.13 & 0.12 \\
\hline Hydroperiod & 0.177 & $<0.001$ & 3.333 & {$[1.386,5.36]$} & 1967 & $<0.001$ & 0.25 & 0.25 \\
\hline \multicolumn{9}{|l|}{ Last 100 years: 1920 through 2019} \\
\hline Total annual precipitation $(\mathrm{cm})$ & 0.130 & 0.06 & 1.696 & {$[-0.047,3.397]$} & 1971 & 0.08 & 0.23 & 0.23 \\
\hline Mean annual temperature $\left({ }^{\circ} \mathrm{C}\right)$ & -0.148 & $<0.05$ & -0.054 & {$[-0.096,-0.004]$} & 1957 & $<0.01$ & 0.13 & 0.09 \\
\hline Annual precipitation minus PET (cm) & 0.134 & $<0.05$ & 2.097 & {$[0.013,4.021]$} & 1970 & 0.09 & 0.21 & 0.21 \\
\hline Hydroperiod & 0.196 & $<0.01$ & 5.949 & {$[1.818,10.154]$} & 1971 & $<0.01$ & 0.25 & 0.25 \\
\hline \multicolumn{9}{|l|}{ Last 50 years: 1970 through 2019} \\
\hline Total annual precipitation $(\mathrm{cm})$ & 0.011 & 0.91 & 0.260 & {$[-5.064,4.679]$} & 1988 & 0.80 & 0.21 & 0.19 \\
\hline Mean annual temperature $\left({ }^{\circ} \mathrm{C}\right)$ & 0.076 & 0.44 & 0.047 & {$[-0.089,0.18]$} & 2015 & 0.55 & 0.19 & 0.19 \\
\hline Annual precipitation minus PET $(\mathrm{cm})$ & -0.433 & 0.66 & -1.578 & {$[-6.52,4.594]$} & 2004 & 0.47 & 0.18 & 0.15 \\
\hline Hydroperiod & -0.017 & 0.87 & -0.952 & {$[-10.0,9.211]$} & 2005 & 0.71 & 0.29 & 0.16 \\
\hline
\end{tabular}

Notes: $95 \% \mathrm{CI}=95 \%$ confidence interval surrounding estimate of Sen's slope. PET is potential evapotranspiration. Hydroperiod is defined as number of days in each water year with stage $\geq 323 \mathrm{~m}$. Maximum autocorrelation refers to the maximum of the absolute values of the autocorrelations computed on annual values using lags from one to 10 years; 1-year lag refers to the correlation between annual values and the values from the preceding year

over the entire hindcasting period (1855-2019), hydroperiod increased on average by 3.3 days per decade. The $95 \%$ confidence interval for this Sen's slope value did not include zero, indicating $>95 \%$ confidence of positive Sen's slope over the hindcasting period. Sen's slope for hydroperiod over the past 100 years (1920-2019) was greater (Fig. 5b; Table 4), with hydroperiod increasing on average by 5.9 days per decade. Pettitt's tests indicated breakpoints in hydroperiod around the year 1970 (Table 4), and hydroperiod from 1970 to 2019 was significantly greater than pre-1970 hydroperiod based on ANOVA and a Tukey's post-hoc test (Fig. 6d). Consistent with a breakpoint circa 1970, hydroperiod showed no significant trends when examining only the post-1970 period (Table 4).

Increasing hydroperiod mirrored increases in local precipitation over time. Over the entire hindcasting period, total annual precipitation increased by $1.9 \mathrm{~cm}$ per decade on average according to Sen's slope (Table 4). Total annual precipitation was significantly greater after 1970 than before based on ANOVA and a Tukey's post-hoc test (Fig. 6a). Unlike precipitation, temperature at the Sinking Pond site did not show clear trends (Table 4), instead increasing significantly over the earlier part of the hindcasting period (from 1870to1919 to 1920-1969) and then decreasing slightly but not significantly over the latter part (from 1920to1969 to 1970-2019; Fig. 6b). Similar to hydroperiod, neither temperature nor precipitation showed significant temporal trends if looking only at the post-1970 period. Unlike with daily or seasonal variables, serial autocorrelation was not a major concern for hydroperiod and annual climate variables. Because maximum autocorrelation values (from one to 10-year lags) and 1-year lag values generally indicated only weak to moderate autocorrelation (Table 4), trend statistics presented here were calculated without pre-whitening (Yue et al. 2002b).

The increasing precipitation trend at the Tullahoma weather station (from which $99.9 \%$ of daily climate records were obtained for use in the Sinking Pond hydrologic model) does not appear to be a regional outlier. Of eight NCEI weather stations selected for comparison (Online Resource 3), four showed significant $(\mathrm{p}<0.05)$ positive trends in total annual precipitation based on a Mann-Kendall test and a partially overlapping set of four stations showed significant positive trends in the number of precipitation days per year (Online Resource 9). Three stations showed no significant trend, and none showed significant negative trends in either total annual precipitation or number of precipitation days per year.

\section{Discussion}

In this study, quadrupling the length of the climatologic and hydrologic record used for calibration and validation and applying more explicit model performance metrics improved the Sinking Pond hydrologic model from Wolfe et al. (2004). The improvement consisted principally of a reduction in bias (i.e., hydroperiod underprediction). In turn, this bias reduction 
Fig. 5 Hydroperiod (days per water year with stage $\geq 323 \mathrm{~m}$ ) from the Sinking Pond hydrologic model, showing (a) yearly values and (b) trends over time, along with (c) trends in mean annual precipitation minus potential evapotranspiration (PET). Details on Sen's slope (for the entire hindcasting period and for the last 100 years, in gray and black dashed lines, respectively) and Pettitt breakpoint analysis are presented in Table 4; these statistics were calculated using yearly values, not moving averages
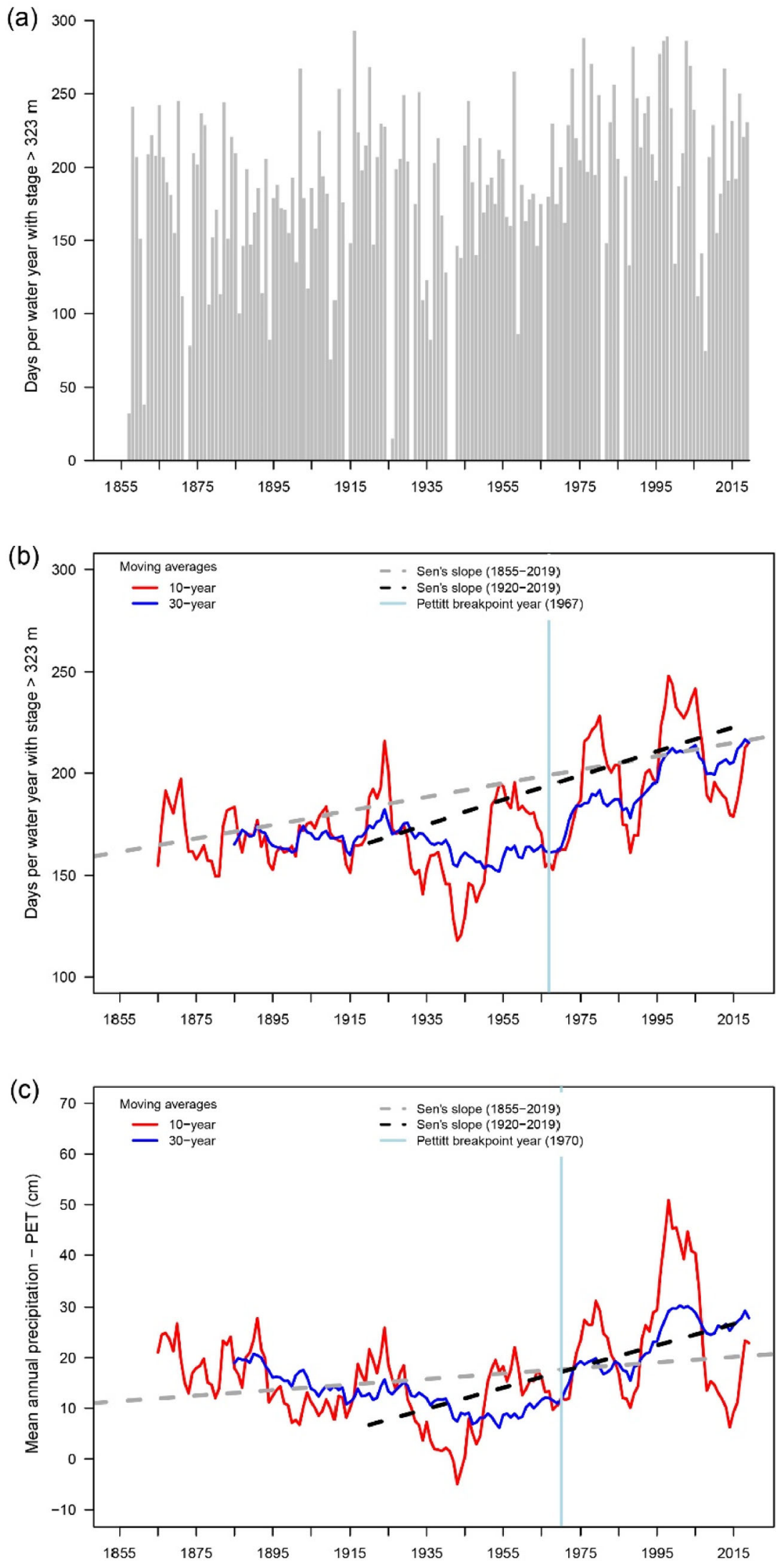
improved model performance in most water years and largely resolved a shortcoming of the original calibration in which the model failed to fill during abnormally dry water years (20062008). The recalibrated model confirmed a finding by Wolfe et al. (2004) of increasing hydroperiod at Sinking Pond beginning around 1970, apparently linked to increasing precipitation (Table 4; Figs. 5 and 6). Notably, this hydroperiod increase is consistent with previous studies showing increased precipitation and streamflow since 1970 in the eastern United States (Karl and Knight 1998; McCabe and Wolock 2002). Although landcover change was not accounted for in the model, forest cover in the Sinking Pond basin increased from the $1940 \mathrm{~s}$ through the early $2000 \mathrm{~s}$ (Wolfe et al. 2004), a trend which, if anything, would be expected to reduce pond inundation because of greater evapotranspiration (Sun et al. 2000;

(a)

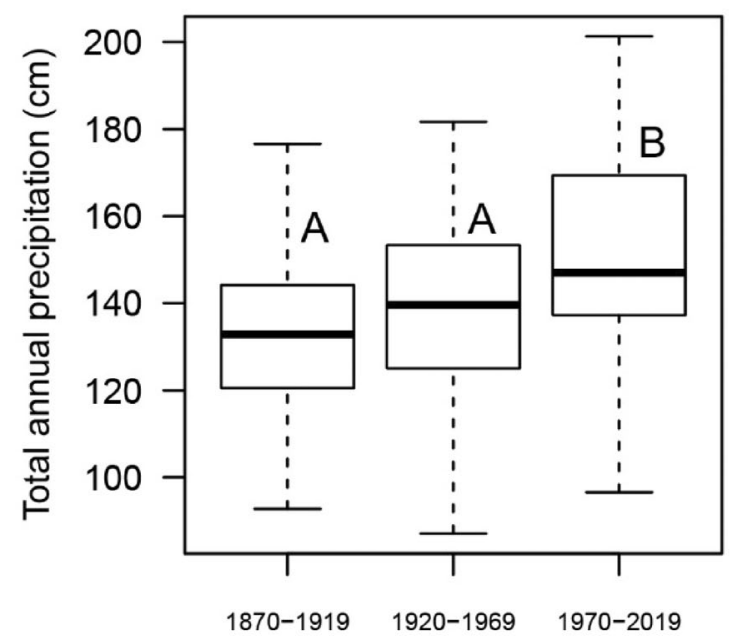

(c)

$F(2,147)=4.32, p<0.05$

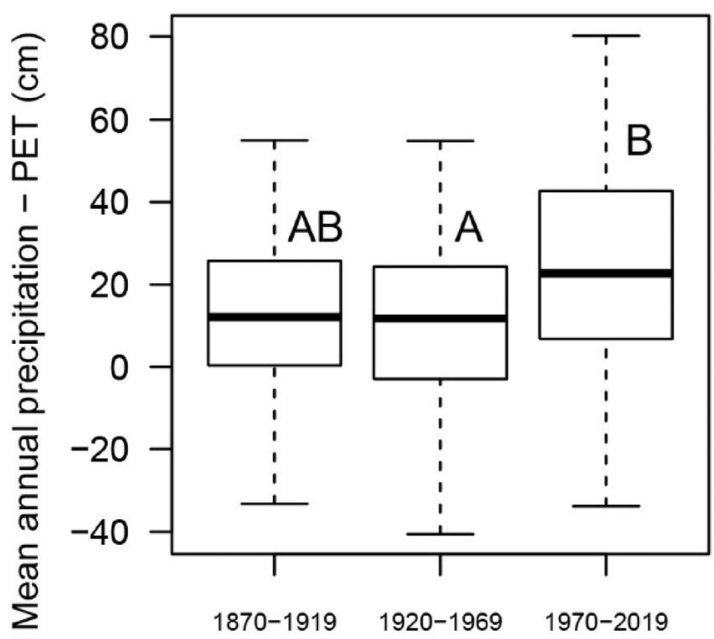

Fig. 6 Boxplots of (a-c) climate variables and (d) hydroperiod from the Sinking Pond hydrologic model, grouped into 50-year time periods from 1870 through 2019. Analysis of variance (ANOVA) results are presented
Jones et al. 2018), suggesting a more likely role for precipitation rather than landcover change in driving hydroperiod increase. Moreover, the potential for hydrologic effects from localized alterations in and around the Sinking Pond siteincluding structural changes to the pond spillway or internal drain as well as waterfowl impoundments in adjacent watersheds - were investigated by Wolfe et al. (2004) using field observations and hydrologic records and were ultimately deemed unlikely to have caused the increase in pond hydroperiod.

Although recalibration improved model performance overall and for several years that were unusually wet or dry, both the original calibration and the recalibration appeared generally successful in simulating daily water levels in hydrologically typical years, indicating adequacy for the purpose of

(b)

$F(2,147)=5.16, p<0.01$

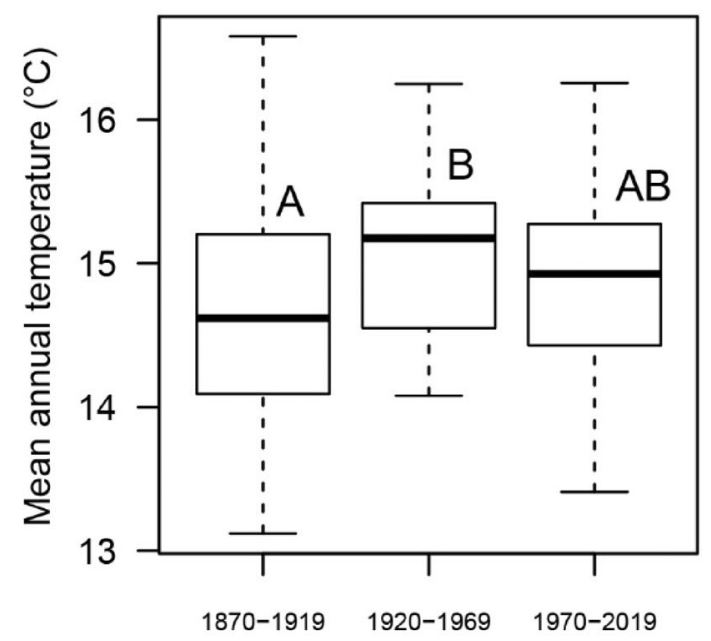

(d) $\quad F(2,147)=6.78, p<0.01$

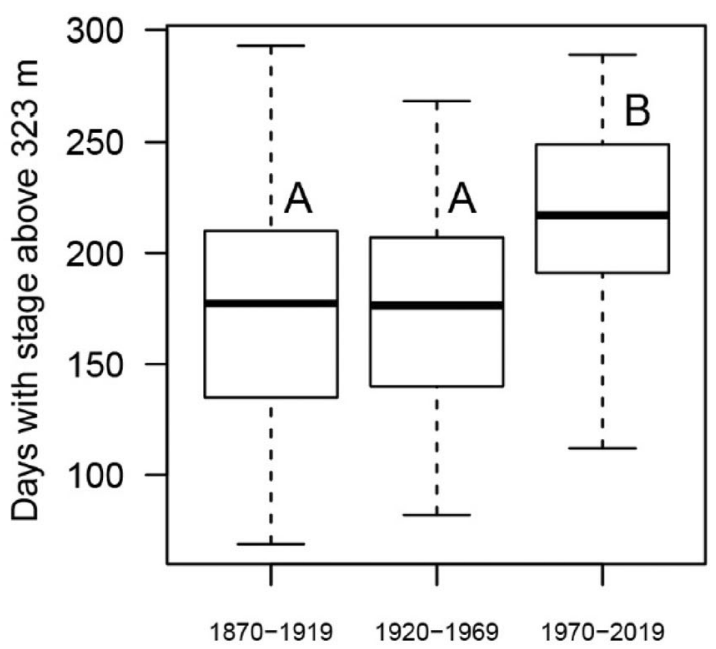

above each plot and letters $(\mathrm{A}, \mathrm{B}, \mathrm{AB})$ represent significant $(\mathrm{p}<0.05)$ differences or lack thereof from a Tukey's post-hoc test 
characterizing secular trends in Sinking Pond's hydrologic regime. Several factors probably account for the adequacy of the original calibration, despite the relatively few (five) years of calibration/validation data that were originally available. The magnitude of the increase in pond hydroperiod produced a reasonably strong signal that might be more readily detected than more subtle or variable trends. In addition, the original modeling effort began with a reasonably firm conceptual model (Fig. 2), based on more than a decade of hydrologic and ecological investigations in the study area (Patterson 1989; Wolfe 1996a, b; Wolfe and League 1996; McCarthy and Evans 2000), whose essential features are preserved in the numerical model's structure and parameterization. Finally, the model's relative simplicity (two compartments, eight transfer terms) and parsimony (four parameters) may have helped mitigate against overspecification and false precision (Beven 1989; Perrin et al. 2001; Lute and Luce 2017).

These considerations suggest that the model structure described here may have some transfer value to similar depression wetlands where inflow is dominated by runoff and internal drainage is tightly coupled to groundwater conditions. It is unclear whether or how that structure could be adapted for other depression wetland systems in the region, such as the shallow, hydraulically perched "karst pans" that coexist along with Sinking Pond and similar features in the Eastern Highland Rim (Wolfe 1996b). In general, model transferability among wetland sites is likely to depend both on intrinsic model characteristics - including simplicity, parsimony, and conceptual basis - as well as climatological, hydrogeologic, and geomorphic similarity among wetland sites. Efforts to adapt the model structure presented here for similar wetland systems could benefit from (1) empirical observations at the sites in question to relate wetland storage to evapotranspiration, groundwater flow, and runoff, (2) evaluation of alternative model formulations (e.g., by scaling PG to SP and/or imposing a lower limit on SP), and (3) use of the freely available and reproducible data and code for the model available from Cartwright (2021).

Although recalibration improved performance of the Sinking Pond hydrologic model and succeeded in approximating pond-stage patterns in most years, poor model performance during two hydrologically atypical years - 2007 and 2009, which each involved multiple filling and draining events - reflects the difficulty of replicating unusually complex hydrographs (Fig. 4, Online Resource 5). Model underperformance in these unusual years is unsurprising in a parsimonious model but raises questions about the degree to which such anomalous water years affected hindcasting accuracy. Of the 138 years prior to the recalibration period beginning in 1993, 11 years $(8 \%$ ) were drier (had lower total annual precipitation) than the driest year in the recalibration dataset, whereas 3 years $(2 \%)$ were wetter than the wettest recalibration year. Thus, a relatively small percentage of hindcasted years would be considered extreme or anomalous based on climate conditions. Furthermore, of the 22 years in the recalibration dataset, all but $3(86 \%)$ had a single, relatively clear pond filling event and a single draining event, including water years 2006 and 2008 which were almost as dry as 2007 (Fig. 4). These two lines of evidence suggest (1) that hydrologically unusual and possibly poorly modelled years probably did occur in the hindcasting period, but also (2) that these years were likely rare compared to years with more moderate climate and simpler hydrographs. Thus, given the overall strength of the hydroperiod trend signal (Table 4), any model limitations in predicting water levels in hydrologically complex or anomalous years are unlikely to have strongly influenced our finding of increased pond hydroperiod over time.

A shift in hydrologic regime of the magnitude shown for Sinking Pond may have profound ecological implications. In common with wetlands generally, biological communities in depression wetlands tend to be shaped by ranges of hydrologic variation and especially by hydroperiod (Brooks 2000; Babbitt 2005; Liston 2006; Stroh et al. 2008; Greenberg et al. 2015; Cartwright and Wolfe 2016; Chandler et al. 2016). Therefore, substantial hydrologic shifts in either direction may degrade wetland ecological integrity. A shift to a drier hydrologic regime may facilitate encroachment of plants and animals from adjacent upland habitats; conversely, a shift to wetter conditions may exceed the physiological tolerance of key wetland species (Cartwright 2019). Hydroperiod changes can produce cascading consequences through wetland ecosystems, as hydroperiod influences diverse ecological processes including amphibian reproduction and population dynamics, litter decomposition and carbon cycling, wetland geochemistry and water quality, and food webs including invertebrate community composition (Golladay et al. 1997; Brooks 2000; Leibowitz and Brooks 2007; Boven et al. 2008; Brooks 2009; Goldyn et al. 2015; Cartwright and Wolfe 2016; Chandler et al. 2016). These linkages underscore the potential importance of climate-driven hydroperiod changes for wetland communities and ecosystems (Greenberg et al. 2015; Lee et al. 2015). Further evaluation of these possible changes at Sinking Pond could employ future hydroperiod projections, leveraging the existing open-source model (Cartwright 2021) combined with temperature and precipitation projections from multiple downscaled climate models to encompass the range of uncertainty across climate models and greenhouse-gas emissions scenarios (Greenberg et al. 2015; Lee et al. 2015; Terando et al. 2020).

In Sinking Pond, the abrupt hydroperiod increase around 1970 appears to have triggered a collapse of tree regeneration, setting the system on a trajectory to transition from a seasonally inundated forested wetland toward a seasonally drained open-water pond (Wolfe et al. 2004). Such pronounced effects of wetland hydrology on vegetation structure have similarly been documented in other depression wetland systems of the 
southeastern United States (De Steven and Toner 2004; Kirkman et al. 2012), such as Carolina bays (Collins and Battaglia 2001; Stroh et al. 2008) and karst-depression wetlands embedded in fire-dependent pine forests (Kirkman et al. 2000). More broadly, hydroperiod has been documented to be a primary determinant of vegetation structure and plant community composition in a variety of wetland types, ranging from sawgrass marsh (Foti et al. 2012) to alluvial floodplain forests (Townsend 2001) to coastal mangroves (Crase et al. 2013). As the potential impacts of climate change on small, geographically isolated wetlands attract further study (Brooks 2009; Cartwright and Wolfe 2016), hydrologic models may become increasingly important for linking meteorological changes in water availability to hydroperiod shifts and resulting ecosystem effects.

Robust hydrologic models for seasonally inundated depression wetlands are important for natural-resource management more broadly, because depression wetlands tend to make substantial contributions to regional biodiversity and because their ecohydrology may be sensitive to climatic fluctuations, human water withdrawals, land-use change, and ecosystem restoration efforts (Tsai et al. 2007; Barton et al. 2008; Brooks 2009; Gómez-Rodríguez et al. 2010; Bird and Day 2014; Park et al. 2014; Cartwright and Wolfe 2016; Bolpagni et al. 2019; Bertassello et al. 2020). In particular, there is a need for models of wetland hydrology to provide temporal extrapolation (i.e., hindcasting and forecasting) in the context of climatic nonstationarity (Greenberg et al. 2015; Lee et al. 2015; Chandler et al. 2016). Although hydroperiod changes may also be detected through other means such as remote sensing (GómezRodríguez et al. 2010; Russell et al. 2020), hydrologic models are generally required for evaluation of hydroperiod dynamics over long (> 50-year) timeframes. Hydrologic hindcasting and forecasting provide unique windows into wetland dynamics that can help wetland managers anticipate future ecological consequences from past and present hydrologic trajectories (Lee et al. 2015; Chandler et al. 2016). To optimize model transferability in time under non-stationary hydroclimatic conditions, wetland models would ideally (1) be grounded in conceptual models informed by prior investigations of wetland geomorphology and landscape context; (2) be calibrated and validated using hydrologic observations from a wide range of climatic conditions, including droughts and wet years; (3) adhere to the parsimony principle to avoid over-fitting; and (4) undergo periodic recalibration as longer hydrologic records become available (Wolfe 1996b; Sun et al. 2006; Kling et al. 2015; Lute and Luce 2017; Jones et al. 2018).

\section{Conclusions}

In this study, we present a recalibrated hydrologic model for Sinking Pond, a seasonally inundated karst-depression wetland on the Eastern Highland Rim in Tennessee, USA. Using 22 years of hydrologic and climate observations, model recalibration provided substantial improvements over the previous calibration (which had used 5 years of observations) and was generally successful in representing pond water levels and hydroperiod across a variety of climatic conditions. We used the recalibrated model to simulate daily water levels over a 165 -year hindcasting period and found strong evidence for precipitation-driven hydroperiod increase after 1970.

These findings suggest several implications for future hydrologic modeling studies in depression wetlands. First, reasonably well-performing hydrologic models for depression wetlands are achievable and can be helpful to anticipate hydroperiod changes and their ecological consequences over time. Second, simplicity and parsimony are valuable features of hydrologic models and in some cases may aid model transferability in time (e.g., hindcasting and forecasting). Third, our findings support the idea that longer periods of hydrologic observations - and especially the representation of climatically extreme years - can help strengthen model robustness in the context of hydroclimatic non-stationarity and increasing climatic variability. Finally, this study underscores the importance of considering the range of climatic variability across the model calibration and validation period in comparison to that of the time period used for temporal extrapolation (e.g., hindcasting), to optimize model accuracy for detecting potential hydroperiod changes over time.

Supplementary Information The online version contains supplementary material available at https://doi.org/10.1007/s13157-021-01474-x.

Acknowledgements This study was supported by a grant from the United States Air Force and benefited from ongoing discussions with Jonathan Evans (University of the South), Scott Gain (U.S. Geological Survey, retired), and Connor Haugh (U.S. Geological Survey, Lower Mississippi-Gulf Water Science Center). The authors wish to thank Jennifer Murphy (U.S. Geological Survey, Central Midwest Water Science Center) and Victor Roland (U.S. Geological Survey, Lower Mississippi-Gulf Water Science Center) and three anonymous reviewers for peer review comments that helped improve the manuscript. Any use of trade, firm, or product names is for descriptive purposes only and does not imply endorsement by the U.S. Government.

Authors' Contributions JC performed the analysis. WW conceived of the study. Both authors designed the study, interpreted the results, co-wrote the manuscript, and conducted revisions of the paper.

Funding This study was supported by the Arnold Engineering Development Complex (U.S. Air Force, Department of Defense) and by the U.S. Geological Survey.

Data Availability Data used in this study are available from Cartwright (2021).

Code Availability Data and R processing scripts used in this study are available from Cartwright (2021). 


\section{Declarations}

Conflict of interest The authors declare no competing interests.

Ethics approval Not applicable.

Consent to participate Not applicable.

Consent for publication Not applicable.

Open Access This article is licensed under a Creative Commons Attribution 4.0 International License, which permits use, sharing, adaptation, distribution and reproduction in any medium or format, as long as you give appropriate credit to the original author(s) and the source, provide a link to the Creative Commons licence, and indicate if changes were made. The images or other third party material in this article are included in the article's Creative Commons licence, unless indicated otherwise in a credit line to the material. If material is not included in the article's Creative Commons licence and your intended use is not permitted by statutory regulation or exceeds the permitted use, you will need to obtain permission directly from the copyright holder. To view a copy of this licence, visit http://creativecommons.org/licenses/by/4.0/.

\section{References}

Arsenault R, Brissette F, Martel JL (2018) The hazards of split-sample validation in hydrological model calibration. Journal of Hydrology 566:346-362. https://doi.org/10.1016/j.jhydrol.2018.09.027

Babbitt KJ (2005) The relative importance of wetland size and hydroperiod for amphibians in southern New Hampshire, USA. Wetlands Ecology and Management 13:269-279. https://doi.org/10.1007/ s11273-004-7521-x

Barton C, Andrews D, Kolka R (2008) Evaluating hydroperiod response in restored Carolina bay wetlands using soil physicochemical properties. Restoration Ecology 16:668-677. https://doi.org/10.1111/j. 1526-100X.2008.00480.x

Berkowitz JF, Johnson DR, Price JJ (2019) Forested wetland hydrology in a large Mississippi River tributary system. Wetlands. https://doi. org/10.1007/s13157-019-01249-5

Bertassello LE, Jawitz JW, Aubeneau AF et al (2019) Stochastic dynamics of wetlandscapes: ecohydrological implications of shifts in hydro-climatic forcing and landscape configuration. Science of the Total Environment 694:133765. https://doi.org/10.1016/j.scitotenv. 2019.133765

Bertassello LE, Rao PSC, Jawitz JW et al (2020) Wetlandscape hydrologic dynamics driven by shallow groundwater and landscape topography. Hydrological Processes 34:1460-1474. https://doi.org/ 10.1002/hyp.13661

Beven K (1989) Changing ideas in hydrology - the case of physicallybased models. Journal of Hydrology 105:157-172. https://doi.org/ 10.1016/S0254-0584(01)00561-2

Bird MS, Day JA (2014) Wetlands in changed landscapes: The influence of habitat transformation on the physico-chemistry of temporary depression wetlands. PLoS One. https://doi.org/10.1371/journal. pone. 0088935

Bolpagni R, Poikane S, Laini A et al (2019) Ecological and conservation value of small standing-water ecosystems: A systematic review of current knowledge and future challenges. Water. https://doi.org/10. 3390/w11030402

Boven L, Stoks R, Forro L, Brendonck L (2008) Seasonal dynamics in water quality and vegetation cover in temporary pools with variable hydroperiods in Kiskunsag (Hungary). Wetlands 28:401-410
Brooks RT (2000) Annual and seasonal variation and the effects of hydroperiod on benthic macroinvertebrates of seasonal forest ("vernal") ponds in central Massachusetts, USA. Wetlands 20:707-715

Brooks RT (2004) Weather-related effects on woodland vernal pool hydrology and hydroperiod. Wetlands 24:104-114

Brooks RT (2009) Potential impacts of global climate change on the hydrology and ecology of ephemeral freshwater systems of the forests of the northeastern United States. Climatic Change 95:469-483. https://doi.org/10.1007/s10584-008-9531-9

Calhoun AJK, Mushet DM, Bell KP et al (2017) Temporary wetlands: Challenges and solutions to conserving a "disappearing" ecosystem. Biological Conservation 211:3-11. https://doi.org/10.1016/j. biocon.2016.11.024

Cartwright J (2019) Ecological islands: conserving biodiversity hotspots in a changing climate. Frontiers in Ecology and the Environment 17: 331-340. https://doi.org/10.1002/fee.2058

Cartwright J (2021) Climate and stage observations and hydrologic model results for Sinking Pond at Arnold Engineering Development Complex, Tennessee. U.S. Geological Survey data release. https:// doi.org/10.5066/P96F7JHP

Cartwright J, Wolfe WJ (2016) Insular ecosystems of the southeastern United States: A regional synthesis to support biodiversity conservation in a changing climate. US Geol Surv Prof Pap 1828. https:// doi.org/10.3133/pp1828

Chandler HC, Rypel AL, Jiao Y et al (2016) Hindcasting historical breeding conditions for an endangered salamander in ephemeral wetlands of the southeastern USA: Implications of climate change. PLoS One 11:1-17. https://doi.org/10.1371/journal.pone.0150169

Chien H, Mackay DS (2014) How much complexity is needed to simulate watershed streamflow and water quality? A test combining time series and hydrological models. Hydrological Processes 28:5624 5636. https://doi.org/10.1002/hyp.10066

Chien H, Mackay DS (2020) Assessing effects of model complexity and structure on predictions of hydrological responses using serial and parallel model design. Hydrological Processes 34:404-419. https:// doi.org/10.1002/hyp.13594

Clark MP, Bierkens MFP, Samaniego L et al (2017) The evolution of process-based hydrologic models: Historical challenges and the collective quest for physical realism. Hydrology and Earth System Sciences 21:3427-3440. https://doi.org/10.5194/hess-21-34272017

Collins B, Battaglia L (2001) Hydrology effects on propagule bank expression and vegetation in six Carolina bays. Community Ecology 2:21-33. https://doi.org/10.1556/ComEc.2.2001.1.3

Coron L, Andréassian V, Perrin C et al (2012) Crash testing hydrological models in contrasted climate conditions: An experiment on 216 Australian catchments. Water Resources Research 48:1-17. https://doi.org/10.1029/2011WR011721

Coron L, Andréassian V, Perrin C et al (2014) On the lack of robustness of hydrologic models regarding water balance simulation: A diagnostic approach applied to three models of increasing complexity on 20 mountainous catchments. Hydrology and Earth System Sciences 18:727-746. https://doi.org/10.5194/hess-18-727-2014

Crase B, Liedloff A, Vesk PA et al (2013) Hydroperiod is the main driver of the spatial pattern of dominance in mangrove communities. Global Ecology and Biogeography 22:806-817. https://doi.org/10. 1111/geb.12063

Davis CL, Miller DAW, Grant EH et al (2019) Linking variability in climate to wetland habitat suitability: is it possible to forecast regional responses from simple climate measures? Wetlands Ecology and Management 27:39-53. https://doi.org/10.1007/s11273-0189639-2

De Steven D, Toner M (2004) Vegetation of upper coastal plain depression wetlands: environmental templates and wetland dynamics within a landscape framework. Wetlands 24:23-42 
Duethmann D, Blöschl G, Parajka J (2020) Why does a conceptual hydrological model fail to correctly predict discharge changes in response to climate change? Hydrology and Earth System Sciences 24:3493-3511. https://doi.org/10.5194/hess-24-3493-2020

Fenneman N (1938) Physiography of the Eastern United States. MacGraw-Hill, New York

Fenneman N, Johnson D (1946) Physical divisions of the United States: US Geological Survey map prepared in cooperation with the Physiographic Commission. U.S. Geological Survey, scale 1:7, 000,000

Fossey M, Rousseau AN, Bensalma F et al (2015) Integrating isolated and riparian wetland modules in the PHYSITEL/HYDROTEL modelling platform: Model performance and diagnosis. Hydrological Processes 29:4683-4702. https://doi.org/10.1002/ hyp. 10534

Foti R, Rinaldo A, Rodriguez-Iturbe I (2012) Hydroperiod regime controls the organization of plant species in wetlands. PNAS 109: 19596-19600. https://doi.org/10.1073/pnas.1218056109

Golden HE, Lane CR, Amatya DM et al (2014) Hydrologic connectivity between geographically isolated wetlands and surface water systems: a review of select modeling methods. Environmental Modelling and Software 53:190-206. https://doi.org/10.1016/j. envsoft.2013.12.004

Golden HE, Sander HA, Lane CR et al (2016) Relative effects of geographically isolated wetlands on streamflow: a watershed-scale analysis. Ecohydrology 9:21-38. https://doi.org/10.1002/eco.1608

Goldyn B, Chudzinska M, Baralkiewicz D, Celewicz-Goldyn S (2015) Heavy metal contents in the sediments of astatic ponds: influence of geomorphology, hydroperiod, water chemistry and vegetation. Ecotoxicology and Environmental Safety 118:103-111. https://doi. org/10.1016/j.ecoenv.2015.04.016

Golladay SW, Taylor BW, Palik BJ (1997) Invertebrate communities of forested limesink wetlands in southwest Georgia, USA: Habitat use and influence of extended inundation. Wetlands 17:383-393. https://doi.org/10.1007/BF03161428

Gómez-Rodríguez C, Bustamante J, Díaz-Paniagua C (2010) Evidence of hydroperiod shortening in a preserved system of temporary ponds. Remote Sensing 2:1439-1462. https://doi.org/10.3390/rs2061439

Greenberg CH, Goodrick S, Austin JD, Parresol BR (2015) Hydroregime prediction models for ephemeral groundwater-driven sinkhole wetlands: a planning tool for climate change and amphibian conservation. Wetlands 35:899-911. https://doi.org/10.1007/s13157-0150680-0

Grigg AH, Hughes JD (2018) Nonstationarity driven by multidecadal change in catchment groundwater storage: a test of modifications to a common rainfall-run-off model. Hydrological Processes 32: 3675-3688. https://doi.org/10.1002/hyp.13282

Haugh C (2006) Hydrogeology and simulation of ground-water flow at Arnold Air Force Base, Coffee and Franklin Counties, Tennessee2002 update. U.S. Geological Survey Scientific Investigations Report 2006-5157. http://pubs.usgs.gov/sir/2006/5157

Huntington TG (2006) Evidence for intensification of the global water cycle: Review and synthesis. Journal of Hydrology 319:83-95. https://doi.org/10.1016/j.jhydrol.2005.07.003

Hyndman R, Athanasopoulos G, Bergmeir C et al (2020) Package "forecast." In: Package "forecast." https://cran.r-project.org/web/ packages/forecast/forecast.pdf

Jakeman A, Hornberger GM (1993) How much complexity is warranted in a rainfall-runoff model? Water Resources Research 29:26372649

Jones CN, McLaughlin DL, Henson K et al (2018) From salamanders to greenhouse gases: does upland management affect wetland functions? Frontiers in Ecology and the Environment 16:14-19. https:// doi.org/10.1002/fee.1744

Jones CN, Ameli A, Neff BP et al (2019) Modeling connectivity of nonfloodplain wetlands: insights, approaches, and recommendations.
Journal of the American Water Resources Association 55:559577. https://doi.org/10.1111/1752-1688.12735

Karl TR, Knight RW (1998) Secular trends of precipitation amount, frequency, and intensity in the United States. Bull Am Meteorol Soc 79:231-241. https://doi.org/10.1175/1520-0477(1998)079<0231: STOPAF $>2.0 . \mathrm{CO} ; 2$

Karl TR, Knight RW, Easterling DR, Quayle RG (1996) Indices of climate change for the United States. Bulletin of the American Meteorological Society 77:279-292

Kendall M (1975) Rank Correlation Methods. Griffin, London

Kirkman LK, Goebel PC, West L et al (2000) Depressional wetland vegetation types: a question of plant community development. Wetlands 20:373-385

Kirkman L, Smith L, Golladay S (2012) Southeastern depressional wetlands. In: Batzer D, Baldwinl A (eds) Wetland habitats of North America: ecology and conservation concerns. University of California Press, Berkeley, pp 203-215

Klemes V (1986) Operational testing of hydrological simulation models. Hydrological Sciences Journal 31:13-24. https://doi.org/10.1080/ 02626668609491024

Kling H, Stanzel P, Fuchs M, Nachtnebel HP (2015) Performance of the COSERO precipitation-runoff model under non-stationary conditions in basins with different climates. Hydrological Sciences Journal 60:1374-1393. https://doi.org/10.1080/02626667.2014. 959956

Lee SY, Ryan ME, Hamlet AF et al (2015) Projecting the hydrologic impacts of climate change on montane wetlands. PLoS One 10: e0136385. https://doi.org/10.1371/journal.pone.0136385

Leibowitz SG, Brooks RT (2007) Hydrology and landscape connectivity of vernal pools. In: Calhoun A, DeMaynadier P (eds) Science and Conservation of Vernal Pools in Northeastern North America. CRC Press, LLC., New York, pp 31-53

Leplastrier M, Pitman AJ, Gupta H, Xia Y (2002) Exploring the relationship between complexity and performance in a land surface model using the multicriteria method. Journal of Geophysical Research: Atmospheres 107:ACL 11-1-ACL 11-12. https://doi.org/10.1029/ 2001JD000931

Liston SE (2006) Interactions between nutrient availability and hydroperiod shape macroinvertebrate communities in Florida Everglades marshes. Hydrobiologia 569:343-357. https://doi.org/10.1007/ s10750-006-0141-0

Lute AC, Luce CH (2017) Are model transferability and complexity antithetical? Insights from validation of a variable-complexity empirical snow model in space and time. Water Resources Research 53:8825-8850. https://doi.org/10.1002/2017WR020752

Magand C, Ducharne A, Le Moine N, Brigode P (2015) Parameter transferability under changing climate: case study with a land surface model in the Durance watershed, France. Hydrological Sciences Journal 60:1408-1423. https://doi.org/10.1080/02626667.2014. 993643

Mann H (1945) Nonparametric tests against trend. Econometrica 13:245259

McCabe GJ, Wolock D (2002) A step increase in streamflow in the conterminous United States. Geophysical Research Letters 29: 2185. https://doi.org/10.1029/2002GL015999

McCarthy S, Evans J (2000) Population dynamics of overcup oak (Quercus lyrata) in a seasonally flooded karst depression. Journal of the Torrey Botanical Society 127:9-18

McLeod AI (2011) Package "Kendall" https://cran.r-project.org/web/ packages/Kendall/Kendall.pdf. Accessed 24 Jun 2020

Moriasi DN, Gitau MW, Pai N, Daggupati P (2015) Hydrologic and water quality models: performance measures and evaluation criteria. Transactions of the ASABE 58:1763-1785. https://doi.org/10. $13031 /$ trans.58.10715 
National Centers for Environmental Information (2020) Climate data online. In: National Oceanic and Admospheric Administration. https:// www.ncdc.noaa.gov/cdo-web/. Accessed 24 Jun 2020

Naughton O, Johnston PM, Gill LW (2012) Groundwater flooding in Irish karst: The hydrological characterisation of ephemeral lakes (turloughs). Journal of Hydrology 470-471:82-97. https://doi.org/ 10.1016/j.jhydrol.2012.08.012

Park J, Botter G, Jawitz JW, Rao PS (2014) Stochastic modeling of hydrologic variability of geographically isolated wetlands: effects of hydro-climatic forcing and wetland bathymetry. Advances in Water Resources 69:38-48. https://doi.org/10.1016/j.advwatres. 2014.03.007

Patterson W (1989) Vegetation and soils of the Sinking Pond area, Coffee County, Tennessee, M.S. Thesis. University of Tennessee

Perrin C, Michel C, Andreassian V (2001) Does a large number of parameters enhance model performance? Comparative assessment of common catchment model structures on 429 catchments. Journal of Hydrology 242:275-301

Perrin C, Michel C, Andre V (2003) Improvement of a parsimonious model for streamflow simulation. Journal of Hydrology 279:275289. https://doi.org/10.1016/S0022-1694(03)00225-7

Pettitt A (1979) A non-parametric approach to the change-point problem. Journal of the Royal Statistical Society 28:126-135. https://doi.org/ 10.1016/j.epsl.2008.06.016

Pohlert (2020) Package "trend". https://cran.r-project.org/web/packages/ trend/vignettes/trend.pdf. Accessed 24 Jun 2020

Pyne M (2000) Biogeographic study of The Barrens of the Southeastern Highland Rim of Tennessee. Revised final draft to Arnold Engineering Development Center, Arnold Air Force Base. Southeast Community Ecology Group, Association of Biodiversity Information, Durham

Qi J, Zhang X, Lee S et al (2019) A coupled surface water storage and subsurface water dynamics model in SWAT for characterizing hydroperiod of geographically isolated wetlands. Advances in Water Resources 131:103380. https://doi.org/10.1016/j.advwatres.2019. 103380

R Core Team (2017) R: A language and environment for statistical computing. In: R Foundation for Statistical Computing, Vienna, Austria. https://www.r-project.org. Accessed 1 Feb 2017

Ritter A, Muñoz-Carpena R (2013) Performance evaluation of hydrological models: statistical significance for reducing subjectivity in goodness-of-fit assessments. Journal of Hydrology 480:33-45. https://doi.org/10.1016/j.jhydrol.2012.12.004

Russell M, Cartwright J, Collins G et al (2020) Legacy effects of hydrologic alteration in playa wetland responses to droughts. Wetlands 40:2011-2024. https://doi.org/10.1007/s13157-020-01334-0

Sen PK (1968) Estimates of the regression coefficient based on Kendall's Tau. Journal of the American Statistical Association 63:1379-1389

Stroh C, De Steven D, Guntenspergen G (2008) Effect of climate fluctuations on long-term vegetation dynamics in Carolina bay wetlands. Wetlands 28:17-27. https://doi.org/10.1672/06-117.1

Sun G, Riekerk H, Kornhak LV (2000) Ground-water-table rise after forest harvesting on cypress-pine flatwoods in Florida. Wetlands 20:101-112. https://doi.org/10.1672/0277-5212(2000)020[0101: GWTRAF]2.0.CO;2
Sun G, Callahan T, Pyzoha J, Trettin C (2006) Modeling the climatic and subsurface stratigraphy controls on the hydrology of a Carolina bay wetland in South Carolina, USA. Wetlands 26:567-580

Terando A, Reidmiller D, Hostetler SW et al (2020) Using information from global climate models to inform policymaking-The role of the U.S. Geological Survey. Open-File Report 2020-1058 25. https://doi.org/10.3133/ofr20201058

Tiner RW (2003) Geographically isolated wetlands of the United States. Wetlands 23:494-516

Townsend PA (2001) Relationships between vegetation patterns and hydroperiod on the Roanoke River floodplain, North Carolina. Plant Ecology 156:43-58

Tsai J, Venne L, McMurry S, Smith L (2007) Influences of land use and wetland characteristics on water loss rates and hydroperiods of playas in the Southern High Plains, USA. Wetlands 27:683-692

U.S. Geological Survey (2020) USGS Water Data for the Nation: U.S. Geological Survey National Water Information System Database. https://doi.org/10.5066/F7P55KJN. Accessed 24 Jun 2020

Vaze J, Post DA, Chiew FHS et al (2010) Climate non-stationarity Validity of calibrated rainfall-runoff models for use in climate change studies. Journal of Hydrology 394:447-457. https://doi. org/10.1016/j.jhydrol.2010.09.018

Wenger SJ, Olden JD (2012) Assessing transferability of ecological models: An underappreciated aspect of statistical validation. Methods in Ecology and Evolution 3:260-267. https://doi.org/10. 1111/j.2041-210X.2011.00170.x

Williams S, Farmer J (2003) Volatile organic compound data from three karst springs in Middle Tennessee, February 2000 to May 2001. U.S. Geological Survey Open-File Report 03-355. https://doi.org/ 10.3133/ofr03355

Wolfe W (1996a) Hydrology and tree-distribution patterns of karst wetlands at Arnold Engineering Development Center, Tennessee. Water-Resouces Investigations Report 96-4277. U.S. Geological Survey, Nashville

Wolfe W (1996b) Karst wetlands of the barrens: geomorphic control of wetland hydrology and plant distribution on the Highland Rim of Tennessee. Ph.D. Dissertation. Clark University

Wolfe W, League D (1996) Water-surface elevations of wetlands and nearby wells at Arnold Air Force Base, near Manchester, Tennessee. Open-File Report 95-753. https://doi.org/10.3133/ ofr 95753

Wolfe W, Evans J, McCarthy S et al (2004) Tree-regeneration and mortality patterns and hydrologic change in a forested karst wetland Sinking Pond, Arnold Air Force Base, Tennessee Water-Resources Investigations Report 03-4217. https://doi.org/10.3133/wri034217

Yue S, Pilon P, Cavadias G (2002a) Power of the Mann-Kendall and Spearman's rho tests for detecting monotonic trends in hydrological series. Journal of Hydrology 259:254-271

Yue S, Pilon P, Phinney B, Cavadias G (2002b) The influence of autocorrelation on the ability to detect trend in hydrological series. Hydrological Processes 16:1807-1829. https://doi.org/10.1002/ hyp. 1095

Publisher's Note Springer Nature remains neutral with regard to jurisdictional claims in published maps and institutional affiliations. 